| Araştırma Makalesi / Research Article |

\title{
Öğretmen Adaylarının Matematiğe Yönelik İmajlarının Akademik Başarı ve Tutumlarıyla ilişskisinin Öğretmen Eğitimi Açısından Doğurguları ${ }^{1}$
}

\section{The Relationship Between the Mathematics Images and Achievement, Attitudes of Teacher Candidates in Terms of Teacher Education}

\section{Funda Uysal' ${ }^{2}$ Hünkar Korkmaz ${ }^{3}$}

\author{
Anahtar Kelimeler \\ akademik başarı \\ hizmet öncesi öğretmen \\ eğitimi \\ hizmet öncesi öğretmen \\ eğitimi programları \\ matematiğe yönelik imaj \\ tutum
}

\section{Keywords \\ academic achievement \\ preservice teacher education \\ pre-service teacher education curricula image of mathematics attitude}

Başvuru Tarihi/Received 16.11.2019

Kabul Tarihi /Accepted 02.05.2020
Öz

Bu araştırmanın amacı; öğretmen adaylarının matematiğe yönelik imajlarını ve bu imajları etkileyen değişkenleri incelemektir. Araştırmada kısmi karma eşzamanlı nicel baskın statülü desen kullanılmışır. Araştırmaya 424 öğretmen adayı katılmıştır. Verileri toplama sürecinde öğretmen adaylarına yönelik imaj anketi, matematiğe yönelik tutum ölçeği ve temel matematik başarı testi kullanılmıştır. Verilerin içerik analizinde, nitel veriler için temalar ve kodlar belirlenerek yüzde verilmiş; nicel veriler içinse MANOVA, kay-kare ve uyum analizi testleri kullanılmıştır. Araştırmanın bulgularına göre matematik başarısı ve tutum puanları farklı program türlerine göre farklılaşırken, sınıf düzeyine göre anlamlı bir şekilde farklılaşmamaktadır. "Matematik" sözcüğü denildiğinde öğretmen adaylarının ilk akıllarına gelenler matematik konuları olmuştur. Cevaplar karşılaştırıldığında gruplar arasında; farklı program türlerine göre anlamlı bir farklııı çıkmazken, sınıf düzeylerine göre anlamlı bir farklılık çıkmıştır. Matematiğe yönelik tutum ve akademik başarı testi puanları ile verilen cevaplar arasındaki ilişki düzeyi ise anlamlıdır. "Matematik" sözcüğünü neye benzettikleri sorulduğunda ise, öğretmen adayları en çok hayata dair konulara değinmişlerdir. Cevaplar gruplar arasında farklı program türleri ve sınıf düzeylerine göre istatistiksel olarak anlamlı bir farklılık göstermezken matematiğe yönelik tutum ve akademik başarı testi puanları ile de ilişkili çıkmamıştır. Benzetme nedenleri ise en çok matematiğe yönelik duygu durumları ile ifade edilmiştir. Verilen cevaplar istatistiksel olarak; farklı sınıf düzeylerine göre anlamlı bir şekilde farklılaşmazken; farklı program türlerine göre anlamlı bir şekilde farklıık göstermektedir. Aynı zamanda cevaplar ile matematiğe yönelik tutum ve akademik başarı testi puanları arasındaki ilişki anlamlıdır.

\section{Abstract}

This study aims to investigate the images of teacher candidates about mathematics and variables affecting images. The study used the partial mixed concurrent quantitative dominant status design. Participants were 424 teacher candidates. Data were collected by using mathematics image survey for teacher candidates, mathematics attitude scale and mathematics achievement test. For analyses of data, themes and codes were identified for qualitative data; percentages, MANOVA, chisquare and correspondence analysis were used for quantitative data. Mathematics success and attitudes varied significantly with respect to program type. These didn't vary significantly based on year of study. The word "mathematics" was mostly associated by teacher candidates with the most common mathematics topics. These didn't vary significantly with respect to program of study. On the other hand, year of study caused a significant difference in these associations, and was related with mathematics achievement and attitude. Considering their associations of "mathematics", teacher candidates most frequently mentioned life. While these didn't vary significantly based on program type or year of study, no relationship was found between mathematics achievement and mathematics attitudes. When asked the reasons for their associations of "mathematics", teacher candidates most commonly mentioned their feelings for mathematics. While these didn't vary significantly with respect to year of study, they varied significantly with respect to program type. They were found to be related with achievement and attitudes.

\footnotetext{
${ }^{1}$ Bu makale, “Öğretmen Adaylarının Matematiğe Yönelik İmajları, Tutumları ve Akademik Başarıları Arasındaki ilişkinin İncelenmesi” başlıklı doktora tezinin bir bölümünden üretilmiştir.

${ }^{2}$ Sorumlu Yazar, Burdur Mehmet Akif Ersoy Üniversitesi, Eğitim Fakültesi, Eğitim Bilimleri Bölümü, Burdur, TÜRKiYE; https://orcid.org/0000-0001-9929-9812

${ }^{3}$ Hacettepe Üniversitesi, Eğitim Fakültesi, Eğitim Bilimleri Bölümü, Ankara, TÜRKiYE; https://orcid.org/0000-0002-5289-1111
} 
Extended Abstract

\section{Introduction}

Knowing the cognitive and affective backgrounds that teacher trainees have brought from the past in the beginning of their teacher training programs is important because of the need to identify the needs in the development of the teacher training program and to provide information about meeting these needs. Cognitive and affective accumulations refer to the concept of image. Image is a mental content that has a visual quality. Cognitively, the individual's thoughts, knowledge and other cognitive representations; affectively, it is related to the attitude, feelings and emotions of the individual and can be explained not only by visual representations, drawings but also by oral representations including metaphors, similes and sentences.

This study aims to investigate the images of first- and fourth-year elementary mathematics, science and elementary education teacher candidates about mathematics; whether their images of mathematics, mathematics achievement and attitudes towards mathematics vary significantly based on several variables (program of study and year of study); and whether a relationship exists between their images of mathematics and their mathematics achievement levels, attitude towards mathematics.

\section{Method}

The study used the partial mixed concurrent quantitative dominant status design. Participants were 424 teacher candidates. Qualitative data were collected by using a mathematics image survey for teacher candidates, while quantitative data were collected by using a mathematics attitude scale and a basic mathematics achievement test. The quantitative data were analyzed with multivariate analysis of variance (MANOVA). For the analyses of qualitative data, themes and codes were identified, and percentages were reported. Furthermore, Chi-square was used to reveal whether program type and year of study created a significant difference. In order to associate qualitative and quantitative data, correspondence analysis was undertaken.

\section{Result and Discussion}

The word "mathematics" was mostly associated by teacher candidates with mathematics topics, the benefits of mathematics, feelings about mathematics and school life.

Considering their associations of the word "mathematics", teacher candidates mentioned the universe, life and tools. Space and nature in the context of the universe in which mathematics is simulated; the life itself, the requirements of life and the rules in life; In the context of the tools are gathered around recreational vehicles and complex vehicles.

When asked the reasons for their associations of the word "mathematics", teacher candidates mentioned their feelings for mathematics, the status of being able to do, the mood for mathematics, the condition they had and the usefulness. The reasons for simulating mathematics are difficult, easy and easy to come back to in the context of the ability to be made; positive feelings, negative feelings, positive feelings and subsequent negative feelings in the context of their feelings for mathematics; be phased and engaged in the context of the necessity; in the context of usefulness, it is gathered around the ease of daily life, the solution of the problems and its being seen as indispensable.

The findings showed that the mathematics success and mathematics attitudes of elementary mathematics education teacher candidates were higher than those of science and elementary education teacher candidates. The mathematics success and mathematics attitudes didn't vary significantly based on year of study.

The word "mathematics" was mostly associated by teacher candidates with the most common mathematics topics. These associations of "mathematics" did not vary significantly with respect to program of study. On the other hand, year of study caused a significant difference in these associations, and was related with mathematics achievement and attitude for all teacher candidates.

Considering their associations of the word "mathematics", teacher candidates most frequently mentioned life. While their associations of the word "mathematics" did not vary significantly based on program type or year of study, no relationship was found between mathematics achievement and mathematics attitudes of teacher candidates from different program types and years of study. When asked the reasons for their associations of the word "mathematics", teacher candidates most commonly mentioned their feelings for mathematics, and more precisely positive feelings. While their reasons for these associations did not vary significantly with respect to year of study, they varied significantly with respect to program type. For all teacher candidates, they were found to be related with mathematics achievement and attitudes. 
Bir program hazırlanırken, ihtiyaç analizi yapılması öğretim programının rasyonelliğini belirleyen önemli adımlardan biridir (Demirel, 2012). Program geliştirme sürecinde bireylerin ihtiyaçları ve ilgi alanları doğru belirlenirse bireylerin etkin katılım göstererek verimli bir şekilde çalışmaları ve böylelikle programın niyet edilen hedeflerine ulaşması sağlanabilecektir (Tyler, 1949). Bu bağlamda herhangi bir düzeyde programın başarısı için öncelikli olarak bireylerin programa giriş özellikleri belirlenmelidir. McDiarmid (1990), öğretmen yetiştirme programlarının geliştirilmesi sürecinde öğretmen adaylarının bilişsel ve duyuşsal birikimlerinin belirlenmesinin önemine ilişkin olarak ise şunu dile getirmiştir: 'Bir öğretmen yetiştiricisi olarak ben, eğer öğrencilerimin neler düşündüklerini, üniversiteye gelirken kafalarında hangi fikirlerle, tecrübelerle geldiklerini ve üniversitede aldıkları derslerde edindikleri fikir, tecrübe ve inançların neler olduğunu bilmezsem, belirleyeceğim araçlar ve hedefler hakkında vereceğim kararlar körü körüne alınmış kararlar olacaktır' (s.17; Akt. Baydar ve Bulut, 2002). Öğretmen yetiştirme programlarına başlarken öğretmen adaylarının geçmişten getirdikleri bilişsel ve duyuşsal birikimlerin bilinmesi; öğretmen yetiştirme programının geliştirilmesi sürecinde ihtiyaçların tanımlaması ve söz konusu ihtiyaçların karşılanması konusunda bilgi vermesi nedeniyle önem taşımaktadır. Bilişsel ve duyuşsal birikimler ise imaj kavramına atıfta bulunmaktadır. İmaj, görsel olarak duyulara ilişkin bir niteliğe sahip zihinsel içeriklerdir (Sam ve Ernest, 2008). Bilişsel olarak, bireyin düşünceleri, bilgisi ve diğer bilişsel temsillerle; duyuşsal olarak, bireyin tutumu, hisleri ve duygularıyla ilişkili olup sadece görsel temsiller, çizimler yoluyla değil, aynı zamanda metaforlar, benzetmeler ve cümleler içeren sözlü temsiller yoluyla da açıklanabilmektedir (Sam, 1999). Metafor, Türk Dil Kurumu sözlüğünde "bir kelimeyi veya kavramı kabul edilenin dışında başka anlamlara gelecek biçimde kullanma" olarak tanımlanmaktadır. Metaforun sadece günlük hayattaki dili süslemeye yönelik olduğu düşünülür ancak metafor, olayların işleyişine yönelik düşünceleri yapılandırarak kontrol eden güçlü bir zihinsel araçtır (Saban, 2004). İmajların metaforlar yoluyla açıklanması mümkündür. Eğer bir kişi bir ifadeyi bir şeyden diğerine aktarırsa, aklında her ikisi için ortak bir şey var demektir.

Çeşitli uluslararası raporlar, Türkiye'deki öğrencilerin matematik başarılarının OECD ülkelerine göre oldukça düşük olduğunu ortaya koymaktadır (Milli Eğitim Bakanlığı [MEB], 2003, 2005, 2010a, 2010b, 2011, 2014). Öğrencilerin matematik başarılarının düşük olması; eğitim sistemi, sosyo-ekonomik durum, öğretim programı, okul, aile, öğretmen ya da öğrenci ile ilgili faktörlerin bir birleşimidir (Eraslan, 2009). Malaty (2006), Sahlberg (2007) ve Simola (2005) öğrencilerin başarılarının kaynakları olarak öğretmen yetiştirme programı, okul yaşamı, kültürel olarak öğretmenlik mesleğine bakış ve hizmet-içi öğretmen eğitimini işaret etmektedirler (Akt. Eraslan, 2009). Bunların doğrultusunda hizmet öncesi öğretmen eğitimi bağlamında düşünüldüğünde, öğrencilerin başarılarını yükseltebilmek; öğretmen adaylarının geleceğin öğretmenleri olarak var olan durumları ve yetiştikleri programlar bağlamında ihtiyaçları ile öğretim süreci sonunda söz konusu ihtiyaçların karşılanma durumlarının belirlenmesini gerekli kılmaktadır. Bu çalışmada da öğretmen adaylarının matematiğe yönelik imajlarının belirlenmesi yoluna gidilmiştir.

Matematiğe yönelik imaj ise zihinsel bir canlandırmayı, matematiğe yönelik bakışı ve tutumu işaret etmektedir. Matematiğin doğasına, matematik yeteneğine ve matematik eğitimine yönelik tutum ve inançların bir bütünü olan matematiğe yönelik imaj, genel olarak matematiğe yönelik bakış, tutum ya da inanç kavramlarıyla beraber kullanılabilmektedir (Sam ve Ernest, 2008). Öğretmen adaylarının matematiğe yönelik imajları için literatürdeki araştırmalarda, öğretmen adayları matematiğin zevkli olduğuna, heyecan verdiği ya da sıkıcı geldiğine, zeka ya da başarıyla da ilişkilendirildiğine (Çalışıcı ve Özçakır Sümen, 2019; Guillaume ve Kirtman, 2010; Güner, 2013; Güveli, İpek, Atasoy ve Güveli, 2011; Şahin, 2013), hayat için gerekli ya da hayatın kendisi olduğuna, hayatı kolaylaştırdığı ya da zorlaştırdığına (Çalışıcı ve Özçakır Sümen, 2019; Erdoğan, Yazlık ve Erdik, 2014; Güler vd., 2012; Güner, 2013), geleneksel yolla yani ezber ya da alıştırma ile öğretilebildiğine (Ball, 1990) değinmişlerdir. Ancak, ERIC, WILSON, British Education Index, Australian Education Index, Social Science Citaton Index veri tabanlarında dil ve yıl sınırlaması konulmadan 2018 yılı sonuna kadar yapılan “teacher education and teachers' images of math, preservice teachers' images of math, teacher education" anahtar kelimeleri ile yapılan aramalarda öğretmen yetiştirme programlarıyla öğretmen adaylarının matematiğe yönelik imajlarında değişimin olup olmadığına yönelik pek bir araştırmaya rastlanmamıştır. Kuzu, Kuzu ve Sıvacı (2018) іMÖ programına devam eden öğretmen adaylarının FBÖ ve isÖ programına devam eden öğretmen adaylarına göre matematik için daha olumlu benzetmeler yaptıklarını belirtmiştir. Tarim, Bulut Özsezer ve Canbazoğlu'nun (2017) çalışmasında ise matematik isÖ programına devam eden öğretmen adayları tarafından sıklıkla hayata benzetilmiştir. Araştırmacıların önemli bir kısmı öğretmenlerin geçmişteki yaşantılarının yanında öğrenim sürecindeki yaşantılarının onların matematiği nasıl öğretecekleri üzerinde oldukça etkili olduğunu ifade etmektedir. Nitekim Gabriele ve Joran (1998), Grant (1996), Johnston ve Whitenack (1992), Riedesel ve Schwartz (1994) öğretmenlerin geçmişteki olumsuz yaşantılarının sınıflarındaki öğrencilerinin matematiği kullanmalarında engelleyici rol oynadıklarına dikkati çekmektedir (Akt. Guillaume ve Kirtman, 2010). Öğretmen adayları öğretmen eğitimine öğretmenlik hakkında belli bir gözlem ve deneyimle başlamaktadır (Lortie, 1975; Akt. Yalaz-Atay, 2003). Bu bağlamda; öğretmen adaylarının öğretmen yetiştirme programlarına başlamadan önceki yaşantılarının yanı sıra öğrenme sürecindeki yaşantılarının da gelecekteki öğretmenlik rollerine etki edebileceği varsayımıyla, onların matematiğe yönelik imajlarının program öncesi ve program sonunda nasıl değiştiğinin saptanması, öğretmen eğitimi programlarının geliştirilmesi açısından önemli ipuçları sağlayacaktır.

$\mathrm{Bu}$ çalışmada öğretmen adaylarının bilişsel boyutlarındaki edinimlerinin tanılanması için matematik başarı testi, duyuşsal özelliklerinin belirlenmesi için de matematiğe yönelik tutum ölçeğinin kullanılması yoluyla; öğretmen adaylarının imajlarını hangi değişken ya da değişkenlerin şekillendirdiğine ilişkin bütünsel bir bilgi edinilebileceği düşünülmüştür. Böylelikle öğretmen adaylarının matematik başarısı ve matematiğe yönelik tutum düzeylerine göre yönelimlerinin bilinmesi ile öğretmen yetiştirme programlarının yeniden düzenlenmesi aşamasında, öğrenme ortamlarının oluşturulmasında nelere dikkat edilebileceğine yönelik 
bulguya dayalı bir kanıt sunulabileceği düşünülmüştür. Ayrıca öğretmen adaylarının matematiğe yönelik imajlarının matematik başarıları ve matematiğe yönelik tutumları ile ilişkilerinin olup olmadığını ortaya koymaya yönelik alan yazında herhangi bir çalışmaya rastlanmamıştır. Bireyin davranışlarında kendi yaşantıları yoluyla kasıtlı istendik davranış değişikliği meydana getirmek (Ertürk, 2016) amacıyla yapılan etkinlikler kapsamında; bireylerin konu alanına yönelik bilişsel boyutta kazanması gereken özelliklere ulaşma dereceleri, yani başarıları, ölçme araçlarıyla saptanmaktadır. Tutum ise Petty ve Cacioppo (1986) için bireylerin kendileri, başkaları veya başka nesne, olay ya da sorunlar için genel değerlendirmeleridir. Brown ve Baird (1993) ile Carpenter ve Lubinski (1990) öğretmenlerin bir konu ya da onun öğretilmesine yönelik tutumlarının, o konuyu öğretirken seçtikleri öğretme yollarını etkilediğini, bunun da öğrenci tutumu üzerinde etkili olduğunu vurgulamaktadır (Akt. Doğan, 2014). Öğretmen adaylarının matematik başarıları ve matematiğe yönelik tutumları için yapılan araştırmalar doğrultusunda; matematik başarıları için yapılan bir araştırmada ilköğretim matematik öğretmenliği öğretmen adaylarının matematik başarılarının daha yüksek olduğu (Gökçek ve Güneş, 2011) belirtilmiştir. Matematiğe yönelik tutum için yapılan araştırmalarda ise öğretmen adaylarının matematiğe yönelik tutumlarının olumlu olduğu ifade edilmiş olup çalışmalarda ilköğretim matematik öğretmenliği öğretmen yetiştirme programına devam edenlerin matematiğe yönelik tutumlarının daha yüksek olduğu (Boran, Aslaner ve Çakan, 2013; Gökçek ve Güneş, 2011) anlaşılmaktadır.

Yukarıda bahsedilenler ışığında bu araştırmanın amacı, ilköğretim düzeyinde matematik öğretmekten sorumlu öğretmen adaylarının matematiğe yönelik imajlarını farklı değişkenler açısından incelemektir. Bu bağlamda araştırma, ilköğretim matematik, fen bilgisi ve sınıf öğretmenliği alanlarında öğrenim görmekte olan birinci ve dördüncü sınıf düzeyindeki öğretmen adaylarının;

(a) matematiğe yönelik imajlarının,

(b) sahip oldukları matematiğe yönelik imajları ile temel matematik başarı testi puanları ve matematiğe yönelik tutum ölçeği puanlarının farklı değişkenlere (öğrenim gördükleri program ve sınıf düzeyine) göre anlamlı bir farklılık gösterip göstermediğinin,

(c) sahip oldukları matematiğe yönelik imajları ile matematik başarı düzeyleri ve matematiğe yönelik tutum düzeyleri arasındaki ilişkinin ortaya konması olmak üzere üç temel problem çerçevesinde yapılandırılmıştır.

\section{YÖNTEM}

Bu araştırmada nitel ve nicel araştırma yöntemlerinin avantajlarından yararlanmak amacıyla karma araştırma yöntemi kullanılmıştır. Çalışma kapsamında karma araştırma yöntemi desenlerinden kısmi karma eşzamanlı nicel baskın statülü desen (partial mixed concurrent dominant status design) kullanıımıştır. Kısmi karma eşzamanlı baskın statülü desende; araştırmada nitel ve nicel veriler aynı zamanda toplanmakta, birine diğerine göre daha çok ağılık verilmekte ve karşılaştırılarak çıkarımlar yapılmadan önce nitel ve nicel veriler ayrı ayrı analiz edilmektedir (Leech ve Onwuegbuize, 2009). Araştırmada veriler eş zamanlı olarak aynı veri toplama aracı üzerinden elde edilmiş, nicel verilere yorumlama aşamasında daha fazla ağırık verilmiştir. İlköğretim matematik, fen bilgisi ve sınıf öğretmenliği programlarında öğrenim gören öğretmen adaylarının matematiğe yönelik imajları için nitel veriler, matematik başarıları ve matematiğe yönelik tutumları için nicel veriler toplanarak matematiğe yönelik imajları(nın); (a) nasıl olduğu, (b) matematik başarısı puanları ve matematiğe yönelik tutum puanlarının öğrenim gördükleri program ve sınıf düzeyine göre anlamlı bir farklılık gösterip göstermediği, (c) ile matematik başarısı düzeyleri ve matematiğe yönelik tutum düzeyleri arasında ilişkinin olup olmadığı analiz edilmiştir.

\section{Çalışma Grubu}

Çalışma grubu oluşturulurken olasılığa dayalı olmayan amaçlı örnekleme yöntemlerinden uygun örnekleme yoluyla, sınıf öğretmenliği (iSÖ), ilköğretim matematik öğretmenliği (iMÖ) ve fen bilgisi öğretmenliği (FBÖ) alanlarında birinci ve dördüncü sınıf öğretmen eğitimi programlarının bulunduğu Ankara ilindeki devlet üniversiteleri belirlenmiştir. Ankara'da bulunan beş devlet üniversitesinden birinin eğitim fakültesi bulunmadığı için; diğerlerinin arasında ise biri yabancı dille eğitim yaptığı, bir diğerinde bu üç programdan fen bilgisi öğretmenliği programı bulunmadığı için araştırma kapsamı dışında bırakılmıştır. Diğer iki üniversiteden birisi ile yapılan ön görüşmelerde bazı anabilim dalı ve sınıf düzeyinde araştırma izni alınamadığı için çalışma kapsamı dışında tutulmuştur. Diğer üniversite ise araştırmacının görev yaptığı üniversitedir. Bu üniversite kolay ulaşılabilirlik kriterini sağladığı için tercih edilmiştir. Çalışmaya gerekli prosedürler, üniversite senatosu etik kurul izni alındıktan sonra başlanmıştır. Çalışma grubuna ilköğretim matematik öğretmenliği öğretmen adaylarının yanı sıra alan eğitiminde matematiği öğretmekten sorumlu, yan dalları matematik olan sınıf öğretmenliği ve fen bilgisi öğretmen adayları dahil edilmiştir. Öğretmen adaylarının imajları, matematik başarıları ve matematiğe yönelik tutumlarının eğitim sürelerince nasıl değiştiğini ortaya koyabilmek için aynı programa yeni başlayan birinci sınıf öğrencileri ve programı tamamlayan dördüncü sınıf öğrencileri ile çalışımıştır. Tablo 1'de program ve sınıf değişkenine göre çalışma grubu yer almaktadır.

Tablo 1. Program ve sınıf düzeyi değişkenine göre çalışma grubu

\begin{tabular}{lcccccc}
\hline \multirow{2}{*}{ Program } & \multicolumn{2}{c}{ Birinci sınıf } & \multicolumn{2}{c}{ Dördüncü sınıf } & \multicolumn{2}{c}{ Toplam } \\
\cline { 2 - 7 } & $\mathrm{n}$ & $\%$ & $\mathrm{n}$ & $\%$ & $\mathrm{n}$ & $\%$ \\
\hline IMÖ & 68 & 16 & 50 & 12 & 118 & 28 \\
FBÖ & 90 & 21 & 51 & 12 & 141 & 33 \\
isÖ & 88 & 21 & 77 & 18 & 165 & 39 \\
\hline Toplam & 246 & 58 & 178 & 42 & 424 & 100 \\
\hline
\end{tabular}


Tablo 1'de görüldüğü üzere araştırmada toplam 424 öğretmen adayı ile çalışılmıştır. Görüldüğü üzere gruptaki öğretmen adaylarının alanlara ve sınıf düzeylerine göre dağılımı benzerdir ve istatistiksel olarak karşılaştırma açısından uygundur.

\section{Veri Toplama Araçları}

Bu araştırma nitel ve nicel veri toplama süreçlerini kapsamaktadır. Nitel verileri toplamak için öğretmen adaylarına yönelik imaj anketi, nicel verileri toplamak için temel matematik başarı testi ve matematiğe yönelik tutum ölçeği kullanılmıştır. Öğretmen adaylarının matematiğe yönelik imajlarını belirlemek için araştırmacı tarafından alanyazında yer alan çalışmalar referans alınarak (Ernest, 2010; Latterell, 2017) bir anket form geliştirilmiştir. Geliştirilen anket form; öğretmen adaylarının matematiği zihinlerinde yaşantılarına dayalı olarak nasıl şekillendirdiklerini belirleyebilmek amacıyla iki açık uçlu sorudan oluşmuştur. Hazırlanan maddeler için 5 ölçme ve değerlendirme uzmanı, 5 program geliştirme uzmanı ve 8 konu alanı uzmanının (5 lise matematik öğretmeninin ve 3 öğretim elemanının) görüşleri alınmıştır. Aracın amaca hizmet etme ve anlaşılabilirlik açısından uygunluğunu belirlemek üzere iki öğretmen adayı ile görüşme yapılmıştır. Geribildirimler sonrasında düzenlenen anket formuna son halini verebilmek üzere de tekrar uzmanlarla görüşme yapılmıştır. Maddeler uzman görüşleri sonrasında; (1) "Matematik" sözcüğünü duyduğunuzda aklınıza gelen ilk şey nedir? (2) "Matematik" sözcüğünü düşünün. Neye benzetirsiniz? Örneğin, matematik bazı insanlar için dondurma gibidir, soğuk ama lezzetli. Niçin benzetirsiniz? şeklini almıştır.

Öğretmen adaylarının matematik derslerine yönelik akademik başarılarını belirlemek amacıyla bir başarı testi geliştirilmiştir. Başarı testinin geliştirilmesinde; belirlenen kazanımlar, ölçülecek özellikleri oluşturmuştur. Bu bağlamda öğretmen adaylarının ortaöğretimde ortak olarak aldıkları matematik dersinin 9. sınıfta olması nedeniyle 9. sınıf matematik dersi kazanımları dikkate alınmıştır. İlgili öğrenme alanları; mantık, kümeler, bağıntı, fonksiyon ve işlem, sayılar şeklindedir. Aynı uzmanlar tarafından temel matematik başarı testine yönelik kazanımların belirlenmesinde; bu kazanımların ilgili diğer kazanımlara göre üst düzeyde, diğerlerini kapsayabilecek nitelikte olmaları dikkate alınmıştır. Her bir kazanım için 2 soru hazırlanmıştır. Maddelerin gözden geçirilmesinin ardından oluşturulan deneme formu ile testin deneme uygulaması yapılmıştır. 25 kazanıma yönelik olarak hazırlanan 50 sorudan oluşan temel matematik başarı testi; esas uygulamanın yapıldığı Yükseköğretim Kurumu'nun iMÖ, FBÖ ve isÖ öğretmen yetiştirme programlarına devam eden toplam 368 ikinci sınıf düzeyindeki öğretmen adayına uygulanmıştır. Uygulamaların yapılabilmesi için öğretmen adaylarının öğretmenlik meslek bilgisi ve alan derslerine giren altı öğretim elemanıyla 2014-2015 akademik yılının yaz döneminde iletişime geçilmiş; 2015-2016 akademik yılı güz döneminin ilk ders haftasında uygulamalar tamamlanmıştır. Uygulama için birinci ve dördüncü sınıf düzeyindeki öğretmen adaylarının seçilmeme nedeni, aynı akademik yılda esas uygulamaların bu sınıf düzeylerine yapılmış olmasıdır. 50 soruluk deneme formuna verilen cevaplar, önce excel programına girilmiş, ardından iteman programıyla madde ayırt edicilik indeksi, madde güçlük indeksi ve çift serili korelasyon katsayısı hesaplanmıştır. Nihai testi oluşturan maddelere karar verilirken ayırtedicilik indeksi 0.40 ve üzerinde olan maddeler seçilmiş, madde güçlük indeksi 1'e yaklaşanlar kolay, 0’a yaklaşanlar zor olarak nitelendirilmiş (Atılgan, 2006) ve orta güçlüğe sahip 25 maddelik bir başarı testi oluşturulmuştur. Testten alınabilecek minimum puan 1, maksimum puan ise $25^{\prime}$ tir. Nihai test için; aritmetik ortalama 14,785 ve ortanca ise $15^{\prime}$ tir. Testin standart sapması 5,671'dir. Diğer taraftan testin varyansı 32,163 , ortalama güçlüğü 0,591'dir. Testin güvenirliği ise 0,865 olup bu değer 0,70 'ten büyük bir değer olduğu için kabul edilebilir bir değerdir. Nihai testte örneğin "kümelerdeki işlemleri kullanarak problemler çözer." kazanımı için "29 kişilik bir gruptaki öğretmen adayları genel kültür ve genel yetenek kurslarından en az birini alacaklardır. Genel kültür kursunu alacak 20, genel yetenek kursunu almayacak 8 öğretmen adayı olduğuna göre her iki kursu alacak kaç öğretmen adayı vardır?" maddesi yer almaktadır.

Öğretmen adaylarının matematiğe yönelik tutumlarını ortaya koymak üzere Duatepe ve Çilesiz (1999) tarafından geliştirilen matematiğe yönelik tutum ölçeği uygulanmıştır. Ölçek, üniversite öğrencilerinin matematiğe yönelik tutumlarını belirlemek amacıyla geliştirildiği için tercih edilmiştir. İlgi ve sevgi, korku ve güven, meslek ve önemlilik, zevk olmak üzere dört boyuttan oluşan toplam 38 maddeden oluşan ölçek; "hiç katılmıyorum, katılmıyorum, kararsızım, kısmen katılıyorum, tamamen katılıyorum” şeklindeki beş seçenekli Likert tipindedir. Ölçek toplam 38 maddeden oluşmakta olup ölçekten alınabilecek minimum puan 5, maksimum puan ise 190'dır. Ölçeğin Cronbach Alfa güvenirlik katsayısı 0,96 olarak bulunmuş olup ölçeğin geçerliği için; ilk boyuttan alınan puanlar ile toplamda alınan puanlar arasındaki korelasyon 0,82, ikinci boyuttan alınan puanlar ile toplamda alınan puanlar arasındaki korelasyon 0,95, üçüncü boyuttan alınan puanlar ile toplamda alınan puanlar arasındaki korelasyon 0,98 ve dördüncü boyuttan alınan puanlar ile toplamda alınan puanlar arasındaki korelasyon 0,96 olarak bulunmuştur (Duatepe ve Çilesiz, 1999). Esas uygulama öncesinde ölçeğin deneme uygulaması; esas uygulamanın yapıldığı Yükseköğretim Kurumu'nun iMÖ, FBÖ ve isÖ öğretmen yetiştirme programlarına devam eden toplam 368 ikinci sınıf düzeyindeki öğretmen adayına yapılmıştır. Uygulamaların yapılabilmesi için öğretmen adaylarının öğretmenlik meslek bilgisi ve alan derslerine giren altı öğretim elemanıyla 2014-2015 akademik yılının yaz döneminde iletişime geçilmiş; 2015-2016 akademik yılı güz döneminin ilk ders haftasında uygulamalar tamamlanmıştır. Uygulama için birinci ve dördüncü sınıf düzeyindeki öğretmen adaylarının seçilmeme nedeni, aynı akademik yılda esas uygulamaların bu sınıf düzeylerine yapılmış olmasıdır. Deneme uygulamasında ölçeğin Cronbach Alfa güvenirlik katsayısı 0,96; 13 maddeden oluşan ilgi ve sevgi boyutu için 0,926, dokuz maddeden oluşan korku ve güven boyutu için 0,901, sekiz maddeden oluşan meslek ve önemlilik boyutu için 0,828 ; sekiz maddeden oluşan zevk boyutu için ise 0,868 olarak bulunmuştur. Tutum ölçeği ile elde edilen dört faktörlü yapının doğrulanıp doğrulanmadığını ortaya koymak üzere ise doğrulayıcı faktör analizi yapılmıştır. Kikare $\left(x^{2}\right)$ ve serbestlik derecesinin oranının 3'ün altında olması mükemmel uyum, 5'in altında olması iyi uyum olduğunu göstermektedir (Kline, 2005). Bu oran $(1694,77) / 659=2,57$ olarak bulunmuştur. Dolayısıyla ölçek mükemmel bir uyum göstermektedir. Ayrıca RMSEA değeri; 0,05'ten küçük olduğunda mükemmel uyum, 0,08 ve eşit ve küçük olduğunda ise iyi uyum

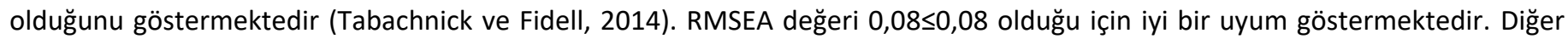

| Kastamonu Eğitim Dergisi, 2020, Vol. 28, No. 4| 
taraftan doğrulayıcı faktör analizine ilişkin bulgular bağlamında; SRMR RFI değeri 0,95 $\leq$ RFI $\leq 1,00$ iken mükemmel uyum ölçütünü göstermekteyken araştırma için 0,96; CFI değeri 0,95 $\leq$ CFI $\leq 1,00$ iken mükemmel uyum ölçütünü göstermekteyken araştırma için 0,98; NFI değeri 0,95 $\leq \mathrm{NFI} \leq 1,00$ iken mükemmel uyum ölçütünü göstermekteyken araştırma için 0,96 olarak bulunmuştur.

\section{Verilerin Toplanması}

Veriler toplanmadan önce yukarıda da belirtildiği üzere araştırmanın yürütüldüğü üniversite senatosunun Etik Komisyonu'ndan izin alınmıştır. Matematik için öğretmen adaylarına yönelik imaj anketi, matematiğe yönelik tutum ölçeği ve temel matematik başarı testi, 2015-2016 akademik yılı güz dönemi başlangıcında, iMÖ, FBÖ ve isÖ birinci sınıf öğretmen adaylarına; 2015-2016 akademik yılı bahar dönemi sonunda, IMÖ, FBÖ ve isÖ son sınıf öğretmen adaylarına uygulanmıştır. Tüm veri toplama araçları birleştirilerek kitapçık haline getirilmiştir. Kitapçık yoluyla her bir öğretmen adayı; tek seferde sırasıyla temel matematik başarı testi, matematiğe yönelik tutum ölçeği ve matematik için öğretmen adaylarına yönelik imaj anketini doldurmuştur. Uygulamalar ortalama olarak 50 dakika sürmüştür. Uygulamaların yapılabilmesi için; birinci sınıf düzeyindeki öğretmen adayları için öğretmen adaylarının öğretmenlik meslek bilgisi derslerine giren üç öğretim elemanıyla iletişime geçilmiş; 2015-2016 akademik yılı güz dönemi başlangıcında ikinci ve üçüncü ders haftasında uygulamalar tamamlanmıştır. Dördüncü sınıf düzeyindeki öğretmen adayları için ise öğretmen adaylarının hem öğretmenlik meslek bilgisi hem de alan derslerine giren dört öğretim elemanıyla iletişime geçilmiş; 2015-2016 akademik yılı bahar dönemi sonunda uygulamalar tamamlanmıştır.

\section{Verilerin Analizi}

Öğretmen adaylarının matematiğe yönelik imajlarının nasıl olduğunu ortaya koyabilmek üzere içerik analizi yoluyla temalar ve kodlar verilmiş, alıntılar yapılmış; çapraz tablolar aracılığıyla yüzde değerleri verilmiştir. Matematik için öğretmen adaylarına yönelik imaj anketi aracılığıyla veri toplama aracında yer alan her açık uçlu soru için; verilen cevaplar yazıya dökülmüş, yazıya dökülen cevaplar sınıflandırılarak kodlar oluşturulmuş, elde edilen kodlar temalar etrafında birleştirilmiş, boş bırakan öğretmen adayı olması durumunda, o öğretmen adayı ya da adayları ilgili soru için analiz dışında bırakılmıştır. Yapılan kodlamalar için uzman görüşleri arasındaki uyumu ortaya koymak üzere Miles ve Huberman'ın (1994) "güvenirlik=görüş birliği sayısı/(görüş birliği sayısı + görüş ayrılığı sayısı)" formülü uygulanmıştır. Bu bağlamda öğrenim görülen her programdan 5 öğretmen adayı olmak üzere toplam 30 öğretmen adayının açık uçlu sorulara verdikleri cevaplar için araştırmacının yanı sıra bir uzman da kodlama yapmıştır. Eğitim Bilimleri alanında doktorasını tamamlamış olan uzman öncelikle imajlar konusunda eğitilmiş, birlikte örnek kodlamalar yapılmıştır. Ardından araştırma için gereken kodlamaların iki uzman tarafından ayrı ayrı yapılması sağlanmıştır. Görüş birliği sağlanan 25 kod aynı kalmış, üç kod revize edilmiş ve \%90 uzmanlar arası uyumla ilgili kodlara karar verilmiştir. \%90 ve üzeri Miles ve Huberman (1994) için kabul edilebilir bir değerdir. Raporlama sürecinde öğretmen adaylarının görüşlerinin neler etrafında toplandığı yüzdeler ve alıntılardan da yararlanarak verilmiştir. Öğretmen adaylarının matematiğe yönelik imajlarının öğrenim gördükleri program ve sınıf düzeyine göre farklııık gösterip göstermediğine yönelik olarak kay-kare yapılmıştır. Araştırmada imajların program türüne ve sınıf düzeyine göre anlamlı fark gösterip göstermediğini ortaya koymak üzere, kay-kare analizlerinde temalar kullanılmıştır. $p$ değeri için anlamlılık düzeyi ise 0,05 olarak alınmıştır.

Öğretmen adaylarının temel matematik başarı testi ve matematiğe yönelik tutum ölçeği puanlarının öğrenim gördükleri program ve sınıf düzeyine göre anlamlı bir farklılık gösterip göstermediği, çok değişkenli varyans analizi (MANOVA) ile test edilmiştir. Çok değişkenli varyans analizine başlamadan önce analizin varsayımları olan tek değişkenli ve çok değişkenli normallik, kovaryans matrislerinin homojenliği, varyansların eşitliği, çoklu bağlantı sorunu ve uç değerleri test edilmiştir. Tablo 2' deki değerler incelendiğinde matematik başarısı ve tutum puanlarının tek değişkenli normalliği sağladıkları fakat çok değişkenli normalliği sağlayamadıkları görülmüştür ( $p<.00)$. Hair ve ark. (2014) MANOVA için gerekli çok değişkenli normallik varsayımın sağlanamaması durumunda eğer örneklem sayıları büyük ise testin gücünün çok az şekilde etkileneceğini belirtmiştir. Bundan dolayı analize devam edilmiştir.

Tablo 2. Tek ve çok değişkenli normallik için değerler

\begin{tabular}{lcccccc}
\hline & \multicolumn{3}{c}{ Tek değişkenli normallik } & \multicolumn{2}{c}{ Çok değişkenli normallik } \\
\cline { 2 - 6 } & Çarpıklık & Çrplk.std. & Basıklık & Bsklk. std & $\chi 2$ & $\mathrm{p}$ \\
\hline Matematik başarı puanı & $-0,874$ & 0,119 & $-1,011$ & 0,119 & \multirow{2}{*}{0,000} \\
$\begin{array}{l}\text { Matematiğe yönelik } \\
\text { tutum puanı }\end{array}$ & 0,786 & $-0,237$ & 0,787 & 0,237 & 111,867 & \\
\hline
\end{tabular}

MANOVA analizinin diğer varsayımlarını incelemek amacıyla Box's M. Levene's test sonuçları ve VIF, TV değerleri Tablo 3’te yer almaktadır.

Tablo 3. Değişkenlere ilişkin Box's M. Levene', VIF ve TV analiz sonuçları

\begin{tabular}{lcccc}
\hline & Box's M test & Levene' test & VIF & TV \\
\hline Matematik başarı puanı & \multirow{2}{*}{0,000} & 0,000 & 0,785 & 1,274 \\
Matematiğe yönelik tutum puanı & & 0,000 & 0,785 & 1,274 \\
\hline
\end{tabular}

Tablo 3 incelendiğinde elde edilen VIF ve TV değerlerinin ölçüt olarak belirlenen değerleri karşıladığı görülmüştür. Fakat Box's $M$ değeri manidar bulunmuştur. Bu ise kovaryans matris eşitliği sağlanamadığını göstermektedir. Bu durumda Wilk's Lambda yerine Pillai's Trace değeri kullanılmıştır (Can, 2013). Bunun dışında değişkenler arasındaki korelasyon katsayıları incelenmiş olup 
matematik başarısı ile tutum puanları arasında korelasyon katsayısı 0,46 olarak hesaplanmıştır. Bu değer bize değişkenler arasında çoklu bağlantı probleminin olmadığını göstermiştir. Tüm bu sonuçlara bakıldığında analizin tüm bu varsayımlarının karşılandığı görülmektedir.

Öğretmen adaylarının matematiğe yönelik imajlarının matematik başarıları ve matematiğe yönelik tutumları ile ilişkisine yönelik olarak uyum analizi yapılmıştır. Değişkenlerin her ikisi de kategorik değişken olduğunda, aralarında ilişkinin olup olmadığını ortaya koymak üzere uyum analizi yapılmaktadır. Değişkenler arasındaki ilişkilerin iki ya da çok boyutlu çapraz tablolarla incelenmesi durumunda kullanılan uyum analizinde, kategoriler arasındaki ilişkiler grafiksel olarak incelenmektedir. Değişken sayısı iki olduğunda basit uyum analizi uygulanmaktadır. Uyum analizinin tek varsayımı çapraz tablolardaki sıklıkların pozitif olmasıdır (Alpar, 2013). Bu araştırmada da öğretmen adaylarının matematik başarıları ve matematiğe yönelik tutumları kategorik hale getirmek üzere gruplandırılmıştır. Üst ve alt gruplar kıyaslanırken, hem gruplar arası farkın hem de örneklem güvenirliğinin en fazla olduğu optimum bir değer bulunmalıdır. Değişik grup mevcutları için sıralanmış puan dizilerinin alt ve üst \%27'lik dilimleriyle oluşturulan gruplarda, alt ve üst grup puanları arasındaki fark ile grup mevcudunun karekökünün çarpımı maksimum olacaktır ve bu istenen bir durumdur (Kelley, 1939; Akt. Can, 2013). Bu çalışmada da başarı veya tutum puanları bakımından öğretmen adaylarının \%27'lik üst grubu yüksek matematik başarısına ya da matematiğe yönelik tutuma sahip, \%27'lik alt grubu düşük matematik başarısına ya da matematiğe yönelik tutuma sahip ve arada kalan \%46'lık grubu ise orta matematik başarısına ya da matematiğe yönelik tutuma sahip olarak kabul edilmiştir. Matematik başarısı bağlamında; yüksek başarılı adayların sayısı 131, orta başarılı adayların sayısı 179 ve düşük başarılı adayların sayısı 114 olmuştur. Matematiğe yönelik tutum bağlamında; yüksek tutuma sahip adayların sayısı 114, orta tutuma sahip adayların sayısı 195 ve düşük tutuma sahip adayların sayısı 115 olmuştur.

\section{BULGULAR}

Bu araştırma kapsamında (a) öğretmen adaylarının matematiğe yönelik imajlarının nasıl olduğu, (b) imajları, matematik başarı düzeyleri ile matematiğe yönelik tutum düzeylerinin program türü ve sınıf düzeyine göre anlamlı bir farklılık gösterip göstermediği, (c) imajları ile matematik başarı düzeyleri ve matematiğe yönelik tutum düzeyleri arasındaki ilişki incelenmiştir. Elde edilen veriler sırasıyla aşağıda yer alan başlıklar altında sunulmuştur.

\section{Öğretmen Adaylarının Matematiğe Yönelik İmajları}

Öğretmen adaylarının matematiğe yönelik imajlarını belirlemek için ilk olarak onlardan "matematik" sözcüğünü duyduklarında ilk akıllarına gelenleri, "matematik" sözcüğünü neye ve niçin benzettiklerini ifade etmeleri istenmiştir. Elde edilen bulgular öğretmenlere yöneltilen sorular bağlamında aşağıdaki alt başlıklar altında verilmektedir.

\section{Matematik Denildiğinde İlk Aklınıza Gelen Nedir?}

Öğretmen adaylarının matematiğe yönelik imajlarını belirlemek için ilk olarak "Matematik denildiğinde ilk aklınıza gelen şeyi yazınız." şeklinde bir yönerge verilmiş ve bu maddeye verilen ifadeler analiz edilmiştir. Öğretmen adaylarının "matematik" sözcüğünü duyduklarında ilk akıllarına gelen şey ile ilgili verdikleri yanıtların içeriğinde "matematiğin faydalarına, matematiğe yönelik duygulara, okul hayatlarına ve matematik konuları"na yönelik ifadeler kullandıkları gözlenmektedir. Bu bağlamda; (a) matematiğin sağladığı faydalara ilişkin görüş bildiren $(\% 20,7)$ öğretmen adaylarının "günlük hayatı kolaylaştırma ve çözüm üretme" şeklinde ifadeler kullandıkları, (b) matematiğe yönelik duygularını yansıtan öğretmen adaylarının $(\% 20,3)$ ifadelerinin içeriklerinde ise; "matematik dersini sevme, sevmeme, korku, kaygı" ifadelerini yansıttıkları, (c) okul hayatlarına yönelik olarak ifadeler kullanan $(\% 9,4)$ öğretmen adaylarının ise "sınıf ortamı ve öğretmen" kavramlarını içeren açıklamalarda bulundukları (d) matematik konularına ilişkin ifadelere yer veren öğretmen adaylarının ise $(\% 48,4)$ ifadelerinde "sayılar, problemler ve diğer matematik konuları" gibi kelimeleri kullandıkları gözlenmektedir. Hiç görüş bildirmeyen öğretmen adayları $(\% 1,2)$ analiz dışında bırakılmıştır. Tablo 4'te ilgili kategori ve alt kategoriler yüzde değerleri ve alıntı örnekleri ile yer almaktadır.

Tablo 4. Matematik dendiğinde ilk akla gelenler için kategori ve alt kategoriler

\begin{tabular}{|c|c|c|c|c|}
\hline Kategori & Yüzde & Alt kategori & Yüzde & Alıntı \\
\hline \multirow[t]{2}{*}{$\begin{array}{l}\text { Matematiğin } \\
\text { faydaları }\end{array}$} & \multirow[t]{2}{*}{20,7} & $\begin{array}{l}\text { Günlük hayatı kolaylaştırma: } \\
\text { Matematiğin hayatı anlamlandırdığına, günlük } \\
\text { hayatta kullanıldığına, yaşam kaynağı olması }\end{array}$ & 5,3 & $\begin{array}{c}\text { Hayatı anlamlandırmayı sağlayan şey (M 423). } \\
\text { Her yerde karşımıza çıkması (S 166). Yaşama } \\
\text { kolaylığı (F 108). Yaşam kaynağı (M 119). Günlük } \\
\text { hayatta bazı konularının kullanıldığı bilim dalı (F } \\
\text { 171). }\end{array}$ \\
\hline & & $\begin{array}{l}\text { Çözüm getirme: } \\
\text { Problem çözme, çözüm yolu bulma, çözülmeyi } \\
\text { bekleyen sorular }\end{array}$ & 15,4 & $\begin{array}{l}\text { Problem çözebilme (M 160). Soru çözmek (F 141). } \\
\text { Işlem yapmak (M 123). Birçok çözüm yolu (S 457). }\end{array}$ \\
\hline \multirow[t]{2}{*}{$\begin{array}{l}\text { Matematiğe } \\
\text { yönelik } \\
\text { duygu }\end{array}$} & \multirow[t]{2}{*}{20,3} & $\begin{array}{l}\text { Matematiğe ilişkin olumlu duygu: } \\
\text { Öğrenmeye istek duyma, matematiği en sevilen } \\
\text { ders olarak görme, matematiği mutlulukla } \\
\text { ilişkilendirme, matematikten zevk alma, eğlenme }\end{array}$ & 14,1 & $\begin{array}{l}\text { En sevilen ders (S 102). Çok zevkli bir ders (F 123). } \\
\text { Heyecan (M133). Mutluluk (F 435). Zevk (S 422). }\end{array}$ \\
\hline & & $\begin{array}{l}\text { Matematiğe ilişkin olumsuz duygu: } \\
\text { Nefret, korku, kaygı duyma }\end{array}$ & 6,2 & $\begin{array}{l}\text { insanlarda korku yaratan bir ders (F 151). Nefret } \\
\text { (S 118). Kaygı (S461). }\end{array}$ \\
\hline
\end{tabular}

| Kastamonu Eğitim Dergisi, 2020, Vol. 28, No. 4| 


\begin{tabular}{|c|c|c|c|c|}
\hline Kategori & Yüzde & Alt kategori & Yüzde & Alıntı \\
\hline \multirow[b]{2}{*}{$\begin{array}{l}\text { Okul } \\
\text { hayatları }\end{array}$} & \multirow[b]{2}{*}{9,4} & $\begin{array}{c}\text { Sınıf ortamı: } \\
\text { Defter, kitap, silgi, başarı, sınav }\end{array}$ & 4,2 & $\begin{array}{l}\text { Kareli defter (S 153). Matematikteki başarı } \\
\text { öyküsü (S 414). Geçilemeyen ders (F 423). }\end{array}$ \\
\hline & & $\begin{array}{c}\text { Öğretmen: } \\
\text { Matematik öğretmenleri, matematiği sevdiren } \\
\text { öğretmenleri, mesleklerinin matematik } \\
\text { öğretmenliği olması }\end{array}$ & 5,2 & $\begin{array}{c}\text { Matematik öğretmenim (M 146). Lisedeki } \\
\text { matematik öğretmenim (F 190). Mesleğim (M } \\
\text { 413). }\end{array}$ \\
\hline \multirow{3}{*}{$\begin{array}{l}\text { Matematik } \\
\text { konuları }\end{array}$} & \multirow{3}{*}{48,4} & Sayılar & 31,8 & Sayılar (F 415). Sayılarla uğraşma bilimi (F 173). \\
\hline & & Problemler & 6 & Problemler (M 161). \\
\hline & & $\begin{array}{l}\text { Diğer matematik konuları: } \\
\text { Fonksiyonlar, integral, türev, trigonometri, } \\
\text { denklemler, limit, logaritma gibi konular }\end{array}$ & 10,6 & $\begin{array}{c}\text { Denklemler (S456). Fonksiyonlar (F 113). } \\
\text { Trigonometri (S 152). }\end{array}$ \\
\hline
\end{tabular}

\section{Matematik Neye Benzer?}

Öğretmen adaylarının "matematik" sözcüğünü neye benzettiklerine ilişkin soruya verdikleri yanıtların "evren, hayat ve araçlar"a yönelik temalar altında toplandığı gözlenmiştir. Hiç görüş bildirmeyen öğretmen adayları $(\% 3,8)$ olmuş ve bunlar araştırma kapsamı dışında tutulmuştur. Tablo $5^{\prime}$ te ilgili kategori ve alt kategoriler yüzde değerleri ve alıntı örnekleri ile yer almaktadır.

Tablo 5. "Matematik" sözcüğünün neye benzetildiğine ilişkin kategori ve alt kategoriler

\begin{tabular}{|c|c|c|c|c|}
\hline Kategori & Yüzde & Alt kategori & Yüzde & Alıntı \\
\hline \multirow[b]{2}{*}{ Evren } & \multirow[b]{2}{*}{12} & Uzay & 4,7 & Uzay (M158). \\
\hline & & Doğa & 7,3 & $\begin{array}{l}\text { Doğa (S411). Ağaç (S149). Deniz (F113). Dallı budaklı kocaman ağaç } \\
\text { (M421). Kaktüs (F126). }\end{array}$ \\
\hline \multirow{3}{*}{ Hayat } & \multirow{3}{*}{51,9} & Hayatın kendisi & 9,2 & Hayat (M111). \\
\hline & & Hayatın gerekleri & 40,6 & Su (M132). Nefes almak (M119). Oksijen (M405). Uyku (S128). \\
\hline & & Hayattaki kurallar & 2,1 & Bisiklet kullanmayı öğrenmek (S419). \\
\hline \multirow{2}{*}{ Araçlar } & \multirow{2}{*}{32,3} & Eğlence araçları & 17,7 & $\begin{array}{l}\text { Puzzle (M121). Lunapark (M124). Kaydırak (M422). Lunaparktaki } \\
\text { gondollar (S459). }\end{array}$ \\
\hline & & Karmaşık araçlar & 14,6 & $\begin{array}{l}\text { Düğüm olmuş kulaklık (F104). Karışmış yün yumağı (F154). Labirent } \\
\text { (F440). Yün yumağı (M137). }\end{array}$ \\
\hline
\end{tabular}

\section{Matematik Neye Benzer? ......'a Neden Benzer?}

Öğretmen adaylarının "matematik" sözcüğünü neye benzettikleri sorulduktan sonra bu benzettikleri kavrama neden benzettiklerine yönelik soruya verdikleri yanıtlar "yapılabilme durumu, matematiğe yönelik duygu durumu, matematiğin gerektirdikleri ve yararı olma durumu" temaları altında gruplandırılmıştır. Aşağıda bu bölüme ilişkin öğretmen adaylarının açıklamalarına ilişkin örnekler sunulmuştur. Hiç görüş bildirmeyen öğretmen adayları (\%5) araştırma kapsamı dışında bırakılmıştır. Tablo 6'da ilgili kategori ve alt kategoriler yüzde değerleri ve alıntı örnekleri ile yer almaktadır.

Tablo 6. "Matematik" sözcüğünün benzetilme nedenlerine ilişkin kategori ve alt kategoriler

\begin{tabular}{|c|c|c|c|c|}
\hline Kategori & Yüzde & Alt kategori & Yüzde & Alıntı \\
\hline \multirow{3}{*}{$\begin{array}{l}\text { Yapılabilme } \\
\text { durumu }\end{array}$} & 16,7 & Zor gelmesi & 9,2 & Zor ulaşırsın (M410). \\
\hline & & Kolay gelmesi & 2,1 & Kolay anlamak (F425). Rahatlıkla soru çözerim (F441). \\
\hline & & Sonradan kolay gelmesi & 5,4 & $\begin{array}{l}\text { Her ne kadar ip yumağını çözmek zor gibi görünse de bir yerden } \\
\text { sonra çorap sökügü gibi açılıverir, kolay gelir (S434). }\end{array}$ \\
\hline \multirow{4}{*}{$\begin{array}{l}\text { Matematiğe } \\
\text { yönelik duygu } \\
\text { durumu }\end{array}$} & 31,8 & $\begin{array}{l}\text { Olumlu duyguya sahip } \\
\text { olunması }\end{array}$ & 13,5 & $\begin{array}{l}\text { Çünkü matematik çözerken daha enerji dolu hissettiğimi fark ettim } \\
\text { kendimi (F430). Soruyu çözmek beni huzurlu ve mutlu kılar (F443). }\end{array}$ \\
\hline & & $\begin{array}{l}\text { Olumsuz duyguya sahip } \\
\text { olunması }\end{array}$ & 7,6 & Bana stres yaşattığından (S160). \\
\hline & & $\begin{array}{l}\text { Yapınca olumlu duyguya } \\
\text { sahip olunması }\end{array}$ & 8,7 & $\begin{array}{c}\text { Başlangıçta korkutucu ama alıştıkça ve öğrendikçe bu zevk başka } \\
\text { hiçbir derste bulunmaz (M130). }\end{array}$ \\
\hline & & $\begin{array}{l}\text { Sonradan olumsuz duyguya } \\
\text { sahip olunması }\end{array}$ & 2 & Belli bir saatten sonra bayıyor insanı (M106). \\
\hline
\end{tabular}




\begin{tabular}{|c|c|c|c|c|}
\hline Kategori & Yüzde & Alt kategori & Yüzde & Alıntı \\
\hline \multirow{2}{*}{$\begin{array}{l}\text { Matematiğin } \\
\text { gerektirdikleri }\end{array}$} & 13,7 & Aşamalı olması & 4,4 & $\begin{array}{c}\text { Adım adım işler sonuca ulaşırsın (M 161). Önceki konuları } \\
\text { öğrenmeden yeni konulara geçilemez (S 417). }\end{array}$ \\
\hline & & Uğraş istemesi & 9,3 & $\begin{array}{c}\text { Matematikte cevabı bulmak zahmetli (M 112). Matematik ile } \\
\text { uğraşmak zaman alabilir (S435). }\end{array}$ \\
\hline \multirow{3}{*}{$\begin{array}{l}\text { Yararlı olma } \\
\text { durumu }\end{array}$} & 16,9 & $\begin{array}{l}\text { Günlük hayatı } \\
\text { kolaylaştırması }\end{array}$ & 4,7 & $\begin{array}{c}\text { Matematiği öğrenen şanslıdır, hayatını kolaylaştırır (M 411). Olursa } \\
\text { daha rahat bir yaşam olur (S 166). }\end{array}$ \\
\hline & & $\begin{array}{l}\text { Problemlere çözüm } \\
\text { getirmesi }\end{array}$ & 5,7 & Matematikte tüm problemlerin cevabı vardır (S 415). \\
\hline & & Vazgeçilmez görülmesi & 6,5 & Onsuz karanlıklar aydınlığa çıkamayacağı için (S 452). \\
\hline
\end{tabular}

\section{Öğretmen Adaylarının Matematiğe Yönelik İmajları, Akademik Başarıları ve Tutumlarının Öğrenim Gördükleri Program ve Sınıf Düzeyine Göre Farklılaşma Durumu}

Öğretmen adaylarının matematiğe yönelik imajları için açık uçlu sorular yoluyla alınan "matematik" sözcüğünü duyduklarında ilk akıllarına ne geldiğinin, "matematik" sözcüğünü neye ve niçin benzettiklerinin; öğrenim gördükleri program ve sınıf düzeyine göre farklılık gösterip göstermediğini ortaya koymak üzere ki-kare testi yapılmıştır:

(a) Program türlerine göre yapılan analizde matematik denildiğinde aklına ilk matematik konuları gelenlerin oranı FBÖ öğretmen adaylarında \%59 iken, isÖ öğretmen adaylarında \%45,7 ve iMÖ öğretmen adaylarında \%41,4'tür; tüm adaylar içinse bu oran \%48,9'dur. Matematiğin faydalarına yönelik ifadelerin oranı ise iMÖ öğretmen adayları için \%25 iken, isö öğretmen adayları için \%20,1 ve FBÖ öğretmen adayları için ise $\% 18,7^{\prime}$ dir; tüm adaylar içinse bu oran $\% 21^{\prime}$ dir. Son olarak matematiğe yönelik duyguların ilk akla gelen ifadeler arasında olmasına yönelik oranı ise isö öğretmen adaylarında \%23,2 iken, imÖ öğretmen adaylarında \%22,4 ve FBÖ öğretmen adaylarında ise \%15,8'dir; tüm adaylar içinse bu oran \%20,5'tir. En az görüş bildirilen okul hayatlarına ilişkin ifadeler bağlamında ise iMÖ öğretmen adayları için oran \%11,2 iken, isÖ öğretmen adaylarında \%11 ve FBÖ öğretmen adaylarında ise \%6,5'tir; tüm adaylar içinse bu oran \%9,5'tir. Farklı program türlerine sahip öğretmen adaylarının "matematik" sözcüğü denildiğinde akıllarına gelenler bağlamında anlamlı bir fark bulunmamıştı, $\chi^{2}(s d=6, n=419)=10,179, p>05$. Programların her biri için öğretmen adaylarının akıllarına matematik konularının gelmesi, lisans öncesinde ya da lisans döneminde içeriğe daha çok önem verilmesinden kaynaklanıyor olabilir.

(b) Sınıf düzeyine göre öğretmen adaylarının aklına ilk matematik konuları gelenlerin oranı dördüncü sınıf düzeyindeki öğretmen adaylarında \%57,1 iken, birinci sınıf düzeyindeki öğretmen adaylarında \%43'tür. Ardından birinci sınıf düzeyindeki öğretmen adaylarında matematiğe yönelik duyguların akla gelme oranı $\% 23,4$ ve matematiğin faydalarına ilişkin görüş bildirenlerin oranı \%21,7'dir. Matematik konularının ardından dördüncü sınıf düzeyindeki öğretmen adayları için ise matematiğin faydalarının akla gelme oranı \%20 iken, matematiğe yönelik duygulara yönelik görüş bildirenlerin oranı \%16,6'dır. Her iki sınıf düzeyinde de en az görüş okul hayatlarına ilişkin olup, oranı birinci sınıf düzeyindeki öğretmen adayları için \%11,9 ve dördüncü sınıf düzeyindeki öğretmen adayları için \%6,3'tür. Farklı sınıf düzeyindeki öğretmen adaylarının "matematik" sözcüğü denildiğinde akıllarına gelenler bağlamında gözlenen farkın anlamlı olduğu bulunmuştur, $\chi^{2}(s d=3, n=419)=9,926, p<, 05$. Gözlenen fark matematik konuları bağlamında dördüncü sınıfların lehine iken; matematiğe yönelik duygular, matematiğin faydaları ve okul hayatı bağlamında birinci sınıfların lehinedir. Bu durumun nedeni, lisans döneminde daha çok uygulama ve duyuşsal boyut yerine konu aktarımı ve içeriğe önem verilmesi olabilir.

(c) Program türlerine göre öğretmen adaylarının "matematik" sözcüğünü neye benzettikleri bağlamında bu sözcüğü hayata benzetenlerin oranı isö öğretmen adaylarında \%57,8 iken, FBÖ öğretmen adaylarında \%51,9 ve imÖ öğretmen adaylarında $\% 50,9^{\prime}$ dur; tüm adaylar içinse bu oran \%53,9'dur. Matematik sözcüğünü araca benzetenlerin oranı FBÖ öğretmen adayları için \%38,9 iken, iMÖ öğretmen adaylarında \%31,9 ve isö öğretmen adaylarında ise \%30,4'tür; tüm adaylar içinse bu oran \%33,6'dır. En az görüş bildirilen evren teması için ise oran iMÖ öğretmen adaylarında \%17,2 iken, isö öğretmen adaylarında \%11,8 ve FBÖ öğretmen adaylarında ise $\% 9,2^{\prime}$ dir; tüm adaylar içinse bu oran $\% 12,5^{\prime}$ tir. Farklı program türlerine sahip öğretmen adaylarının "matematik" sözcüğünü neye benzettiklerine yönelik ifadeleri arasında istatistiksel olarak anlamlı bir fark bulunmamışır, $\chi^{2}(\mathrm{sd}=4$, $n=408)=5,748, p>, 05$. Bu sonuca dayalı olarak programların her biri için öğretmen adaylarının matematiği hayata benzetmeleri, matematiği yaşamlarının bir parçası olarak algıladıkları şeklinde yorumlanabilir.

(d) Sınıf düzeyine göre "matematik" sözcüğünü neye benzettikleri bağlamında bu sözcügü hayata benzetenlerin oranı birinci sınıf düzeyindeki öğretmen adaylarında \%55,9 iken, dördüncü sınıf düzeyindeki öğretmen adaylarında $\% 51,2$ 'dir. Matematik sözcüğünü araca benzetenlerin oranı ise dördüncü sınıf düzeyindeki öğretmen adaylarında \%34,1 iken, birinci sınıf düzeyindeki öğretmen adaylarında ise \%33,2'dir. En az görüş bildirilen evren için ise oran dördüncü sınıf düzeyindeki öğretmen adaylarında $\% 14,7$, birinci sınıf düzeyindeki öğretmen adaylarında \%10,9'dur. Farklı sınıf düzeylerine sahip öğretmen adaylarını "matematik" sözcüğ̈̈ benzettikleri bağlamında anlamlı bir fark bulunmamıştır, $\chi^{2}(s d=2, n=408)=1,567, p>05$. Bu bulgu, programa başlarken matematiği yaşamla ilişkilendiren öğretmen adaylarının, programı tamamladıklarında da bunu devam ettirebileceklerine yönelik bir tespit olarak yorumlanabilir.

(e) Program türlerine göre "matematik" sözcügünü benzettikleri kavrama yönelik benzetme nedeni olarak açıklamalarında en fazla yansıttıkları duygu durumlarına ilişkin görüş bildirme oranları FBÖ öğretmen adaylarında \%37,2 iken, iMÖ öğretmen 
adaylarında \%31,9 ve isö öğretmen adaylarında \%31,6'dır. İkinci sırada benzetme nedeni olarak yararlı olma durumuna yönelik ifadeler analiz edildiğinde iMÖ’deki öğretmen adaylarının \%28,4'ü, isö’deki öğretmen adaylarının \%18,4'ü ve FBÖ’deki öğretmen adaylarının \%17,1'i bu temaya ilişkin görüş bildirmişlerdir. Öğretmen adaylarının program türlerine göre "matematik" sözcüğünü benzettikleri kavrama yönelik benzetme nedenleri olarak belirttikleri ifadeler açısından yapılan ki-kare testi sonucunda gözlenen farkın anlamlı düzeyde olduğu tespit edilmiştir, $\chi^{2}(s d=12, n=403)=27,283, p<, 05$. Gözlenen fark; yararlı olma durumu ile birden fazla görüş bildirme bakımından ve matematiğe yönelik duygu ve matematik disiplinin gerektirdikleri ile ilgili ifadeler açısından iMÖ programında öğrenim gören öğretmen adaylarının; matematiğe yönelik duygu durumu ile birden fazla görüş bildirme bakımından ve matematiğe yönelik duygu ve yapılabilme durumu bağlamında ise FBÖ programında öğrenim gören öğretmen adaylarının lehinedir.

(f) Sınıf düzeyine göre "matematik" sözcügünü benzetme nedeni olarak sahip oldukları duygu durumlarına ilişkin görüş bildirme oranları birinci sınıf düzeyindeki öğretmen adaylarında \%38,2 iken, dördüncü sınıf düzeyindeki öğretmen adaylarında \%27,1'dir. Yararlı olma durumuna ilişkin dördüncü sınıf düzeyindeki öğretmen adaylarının oranı \%23,5, birinci sınıf düzeyindeki öğretmen adaylarının oranı \%16,3'tür. Gerekçe olarak tek bir görüş bildiren öğretmen adaylarının yanıtları analiz edildiğinde birinci sınıf düzeyindeki öğretmen adayları en az matematiğin gerektirdiklerinin olması durumuna \%11,6 oranla değinirken, dördüncü sınıf düzeyindeki öğretmen adayları yapılabilme durumuna \%16,5 oranında değinmişlerdir. Birden fazla görüş bildiren öğretmen adaylarının yanıtları analiz edildiğinde ise birinci $(\% 10,3)$ ve dördüncü $(\% 7,6)$ sınıf düzeyindeki öğretmen adayları çoğunlukla matematiğe yönelik duygu ve yapılabilme durumuna değinmişlerdir. Birinci sınıf düzeyindeki öğretmen adayları açıklamalarında matematiğe yönelik duygu ve yararlı olma durumuna $(\% 5,2)$, dördüncü sınıf düzeyindeki öğretmen adayları ise matematiğe yönelik duygu ve yararlı olma durumuna $(\% 3,5)$ ve matematiğe yönelik duygu ve gerektirdiklerinin olması durumuna $(\% 3,5)$ aynı oranda değinmişlerdir. Öğretmen adaylarının sınıf düzeylerine göre "matematik" sözcüğünü benzettikleri kavram için benzetme nedenlerine yönelik ifadeleri arasında istatistiksel olarak anlamlı bir fark gözlenmemiştir, $\chi^{2}(s d=6, n=403)=11,127, p>, 05$. Bu bulgu, öğretmen adaylarının programa başlarken ve programı tamamladıklarında matematiğe yönelik olarak daha çok, duygularını dikkate aldıklarını bu bağlamda öğretmen eğitimi sürecinde onların ilgilerini, tutumlarını, motivasyonlarını arttıran ve dikkate alan bir düzenlemenin yapılmasının önemine yönelik değerlendirilebilir.

(g) Öğretmen adaylarının matematik başarıları ve matematiğe yönelik tutumlarının sınıf düzeylerine ve öğrenim gördükleri programlara göre anlamlı bir farklılık gösterip göstermediği çok değişkenli varyans analizi (MANOVA) ile test edilmiştir. Varsayımları sağlanan MANOVA analizi sonuçları ise Tablo 7'de verilmiştir.

Tablo 7. Matematik başarısı ve tutum puanları ile bağımsız değişkenler arasında yapılan MANOVA sonuçları

\begin{tabular}{lcccccc}
\hline & Pillai's Trace & $F$ & Hip. Sd & Hata Sd. & P & $\eta 2$ \\
\hline Program & 0,157 & 17,517 & 4 & 824 & 0,000 & 0,078 \\
Sinıf & 0,012 & 2,516 & 2 & 411 & 0,082 & 0,012 \\
\hline
\end{tabular}

Tablo 7'ye göre matematik başarı ve tutum puanları sınıf değişkenine göre (Pillai's Trace=.012, $F(2,411)=2.516)$ istatistiksel olarak manidar farklılık göstermemektedir. Buna karşın matematik başarı ve tutum puanları program (Pillai's Trace=.157, $F(2$, 824)=17.517, $\mathrm{p}<.01$ ) değişkenine göre istatistiksel olarak anlamlı bir farklılık göstermektedir. Etki boyutu açısından bu etkinin orta büyüklükte bir etki olduğu görülmüştür. Bölüm değişkeninde ortaya çıkan bu farklılıkların hangi alt boyutlarda olduğunun incelenmesi için yapılan varyans analiz sonucu da Tablo 8'de verilmiştir.

Tablo 8. Program değişkenine ilişkin yapılan varyans analizi sonuçları

\begin{tabular}{lccccccc}
\hline Bağımlı değişkenler & Kareler toplam & sd & Kareler ort. & $F$ & $p$ & $\eta 2$ & Manidar fark \\
\hline Matematik başarı p. & 917,545 & 2 & 458,772 & 35,020 & 0,000 & 0,145 & $\begin{array}{l}\text { lilk. Mat- Fen } \\
\text { ilk. Mat-Sınıf }\end{array}$ \\
Tutum p. & 20341,641 & 2 & 10170,821 & 14,194 & 0,000 & 0,064 & $\begin{array}{l}\text { Illk. Mat- Fen } \\
\text { ilk. Mat-Sınıf }\end{array}$ \\
\hline
\end{tabular}

Tablo 8 incelendiğinde program değişkeni bağlamında hem matematik başarı testi puanları hem de tutum testi puanları açısından istatistiksel olarak anlamlı düzeyde farklılık gözlenmiştir. Ortaya çıkan farklılıkların kaynağını belirlemek için tüm değişkenler için Tamhane (T2) testi yapılarak çoklu karşılaştırma yapılmıştır. Matematik başarı testi puanları açısından iMÖ programına kayıtlı öğretmen adaylarının lehine olacak şekilde bir farklııı gözlenmektedir. Bu farklılığın pratikte büyük bir etkiye sahip olduğu söylenebilir. Benzer biçimde tutum puanları açısından da İMÖ programına kayıtlı öğretmen adaylarının lehine olacak şekilde farklılık göstermiştir. Bu etki ise pratikte orta büyüklüktedir.

\section{Öğretmen Adaylarının Matematiğe Yönelik İmajlarının Başarı ve Tutum Düzeyleri île i̇lişkisi}

Öğretmen adaylarının matematiğe yönelik imajlarını belirlemek amacıyla "matematik" sözcüğünü neye ve niçin benzettiklerine yönelik ifadeleri ile matematik testi başarı puanları ve matematiğe yönelik tutum puanları düzeyleri arasındaki ilişkiyi ortaya koymak amacıyla yapılan uyum analizi sonucunda elde edilen boyutlar ve inertia değerlerine ilişkin veriler Tablo 9'da yer almaktadır. 
Tablo 9. Öğretmen adaylarının "matematik" sözcüğünü duyduklarında ilk akıllarına gelenler ve matematik başarısı düzeyi için boyut sayısı ve açıklanan inertia değerleri

\begin{tabular}{lcccccc}
\hline Boyut & Tekil değer & Inertia & $\chi^{2}$ & $P$ & \multicolumn{2}{c}{ Açıklanan inertia } \\
\cline { 5 - 7 } & & & & & Açıklanan & Toplamalı \\
2 & 0,169 & 0,029 & & 0,890 & 0,890 \\
Toplam & 0,059 & 0,004 & 13,427 & $0,037^{*}$ & 0,110 & 1 \\
$*$ p $<0,05$ & & 0,032 & & & 1 & 1 \\
\end{tabular}

Tablo 9 incelendiğinde inertianın $0^{\prime}$ dan farklı olup olmadığına yönelik olarak yürütülen ki-kare testi sonucunda toplam inertianın 0'dan farklı olduğu gözlenmektedir $\left(\chi^{2}(6)=13,427, p<, 05\right)$. Bu bulguya göre öğretmen adaylarının "matematik" sözcüğünü duyduklarında ilk akıllarına gelen ifadelerin matematik başarısı testi puanları ile ilişkili olduğu, bunların birbirinden bağımsız olmadığı söylenebilir. Ayrıca toplam inertianın \%89'luk kısmının birinci boyut, \%11'lik kısmının ise ikinci boyut tarafından açıklandığı görülmektedir. İki boyut tüm değişkenliği açıklamaktadır.

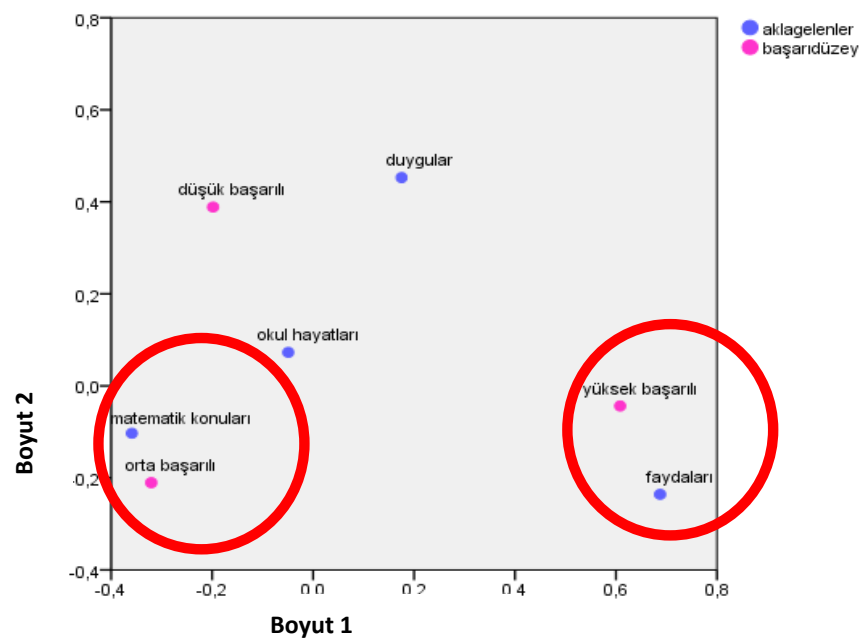

Şekil 1. Öğretmen adaylarının "matematik" sözcüğünü duyduklarında ilk akıllarına gelenler ve matematik başarısı düzeyleri için satır ve sütun noktalarının düzlemde birlikte gösterimi

Şekil 1 incelendiğinde başarı testinden yüksek puan alan öğretmen adaylarının matematiğin faydalarına, başarı testinden orta düzeyde puan alan öğretmen adaylarının ise matematik konularına yöneldikleri gözlenmektedir. Düşük başarı testi puanına sahip öğretmen adaylarının ise okul hayatına ve matematiğe yönelik duygulara benzer şekilde yöneldikleri gözlenmektedir. Matematik denildiğinde ilk olarak okul hayatına yönelik ifadeleri kullanan grubun düşük ve orta düzeyde başarı testi puanı alan öğretmen adayları olduğu gözlenmektedir. Matematiğin günlük hayatı kolaylaştırmasına ve çözüm üretmesine yönelik ifadeleri, başarısı yüksek olan öğretmen adaylarının; matematiğe yönelik olumlu ya da olumsuz duygulara yönelik ifadeler ile öğretmen ya da sınıf ortamına yönelik ifadeleri ise başarı düzeyi düşük olan öğretmen adaylarının kullandığı gözlenmektedir. Matematik başarı testinden yüksek puan alan öğretmen adaylarının matematiğin günlük hayatı kolaylaştırmasına ya da çözüm üretmesine değinmeleri, beklenen ve istenilen bir durumdur. Böylece öğretimin buna göre şekillendirilebileceği düşünülmektedir. Öğretmen adaylarının "matematik" sözcüğünü duyduklarında ilk akıllarına gelen ifadelerin matematiğe yönelik tutum testi puan düzeyleri ile ilişkili olup olmadığını ortaya koymak üzere uyum analizi sonucunda elde edilen boyutlara ve inertiaya ilişkin veriler ise Tablo 10 'dadır.

Tablo 10. Öğretmen adaylarının "matematik" sözcüğünü duyduklarında ilk akıllarına gelenler ve matematiğe yönelik tutum düzeyi için boyut sayısı ve açıklanan inertia değerleri

\begin{tabular}{|c|c|c|c|c|c|c|}
\hline \multirow[t]{2}{*}{ Boyut } & \multirow[t]{2}{*}{ Tekil değer } & \multirow[t]{2}{*}{ Inertia } & \multirow[t]{2}{*}{$\chi^{2}$} & \multirow[t]{2}{*}{$P$} & \multicolumn{2}{|c|}{ Açıklanan inertia } \\
\hline & & & & & Açıklanan & Toplamalı \\
\hline 1 & 0,189 & 0,036 & 19,950 & $0,003^{*}$ & 0,752 & 0,752 \\
\hline 2 & 0,109 & 0,012 & & & 0,248 & 1 \\
\hline Toplam & & 0,048 & & & 1 & 1 \\
\hline
\end{tabular}

Tablo 10 incelendiğinde inertianın 0 'dan farklı olup olmadığına yönelik olarak yürütülen ki-kare testi sonucunda toplam inertianın 0'dan farklı olduğu görülmektedir $\left(\chi^{2}(6)=19,950 p<, 05\right)$. Buna göre satır ve sütun değişkenleri arasında bir ilişki olduğu, satır ve sütunların birbirinden bağımsız olmadığı söylenebilir. Ayrıca toplam inertianın \%75,2'lik kısmının birinci boyut, \%24,8'lik kısmının ise ikinci boyut tarafından açıklandığı görülmektedir. İki boyut tüm değişkenliği açıklamaktadır. 


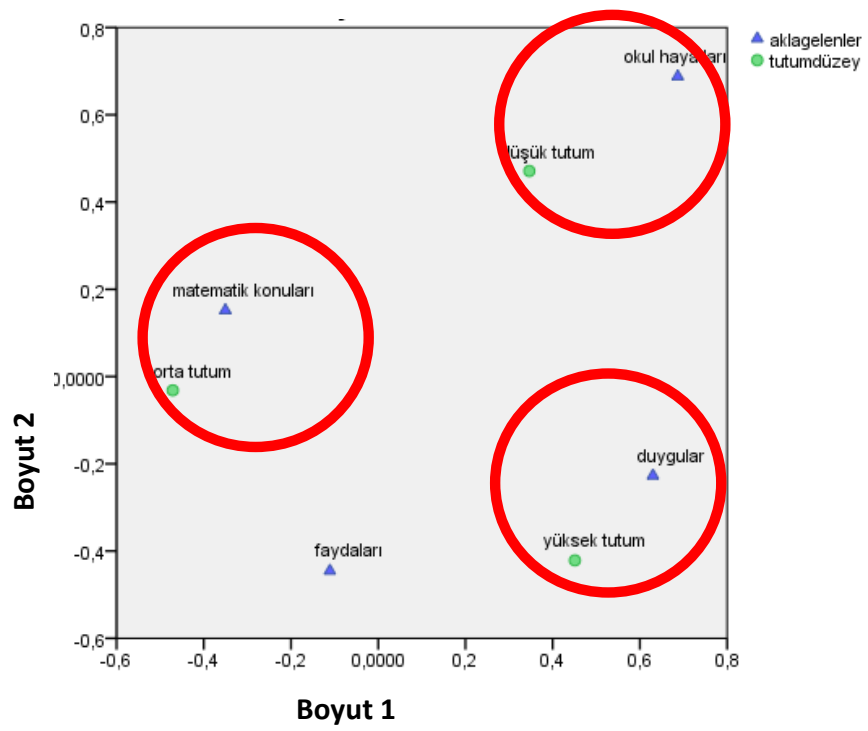

Şekil 2. Öğretmen adaylarının "matematik" sözcüğünü duyduklarında ilk akıllarına gelenler ve matematiğe yönelik tutum düzeyi için satır ve sütun noktalarının düzlemde birlikte gösterimi

Şekil 2 incelendiğinde yüksek tutum testi puanı alan öğretmen adaylarının matematiğe yönelik duygularını yansıtan, orta düzeyde tutum testi puanı alan öğretmen adaylarının matematik konularına, düşük düzeyde tutum testi puanı alan öğretmen adaylarının ise okul hayatlarına yönelik ifadeler kullandıkları gözlenmektedir. Matematiğin faydalarına yönelik ifadelere bir yönelme gözlenmemiştir. Matematiğe yönelik olumlu ya da olumsuz duyguya tutum testinden yüksek puan olan öğretmen adaylarının; öğretmen ya da sınıf ortamına yönelik ifadelere ise tutum testi puanı düşük olan öğretmen adaylarının yöneldikleri gözlenmektedir. Matematiğe yönelik duyguları yansıtan ifadelere yüksek tutum testi puanına sahip olan öğretmen adaylarının yönelmeleri beklenen bir bulgudur. Öğretmen eğitimi programlarında öğretmen adaylarının matematiğe yönelik olumlu duyguya sahip olmalarını sağlayacak öğrenme-öğretme ortamlarının oluşturulmasına, gelecekteki öğrencilerine bu duyguları yansıtacaklarını varsayarak, dikkat edilmelidir. Öğretmen adaylarının "matematik" sözcüğünü neye benzettiklerine yönelik ifadelerinin matematik başarı düzeyleri ile ilişkili olup olmadığını ortaya koymak üzere uyum analizi sonucunda elde edilen boyutlara ve inertiaya ilişkin veriler Tablo 11'dedir.

Tablo 11. Öğretmen adaylarının "matematik" sözcüğünü neye benzettiklerine yönelik ifadeler ile matematik başarısı düzeyi için boyut sayısı ve açıklanan inertia değerleri

\begin{tabular}{lcccccc}
\hline Boyut & Tekil değer & Inertia & \multirow{2}{*}{$\chi^{2}$} & $p$ & \multicolumn{2}{c}{ Açıklanan inertia } \\
\cline { 6 - 7 } & & & & & Açılkanan & Toplamalı \\
\hline 1 & 0,104 & 0,011 & & & 0,805 & 0,805 \\
2 & 0,051 & 0,003 & 5,483 & 0,241 & 0,195 & 1 \\
Toplam & & 0,013 & & & 1 & 1 \\
\hline
\end{tabular}

Tablo 11'e göre satır ve sütun değişkenleri arasında bir ilişki bulunmamaktadır $\left(\chi^{2}(4)=5,483, p>, 05\right)$. Buna göre satır ve sütunların birbirinden bağımsız olduğu söylenebilir. Öğretmen adaylarının "matematik" sözcüğünü neye benzettiklerine yönelik ifadelerinin matematik başarısı düzeyi ile ilişkili olmadığı anlaşılmaktadır. Öğretmen adaylarının "matematik" sözcüğünü neye benzettiklerine yönelik ifadelerin matematiğe yönelik tutum düzeyi ile ilişkili olup olmadığını ortaya koymak üzere yapılan uyum analizi sonucunda elde edilen boyutlara ve inertiaya ilişkin veriler Tablo 12 'dedir.

Tablo 12. Öğretmen adaylarının "matematik" sözcüğünü neye benzettiklerine yönelik ifadeler ile matematiğe yönelik tutum düzeyi için boyut sayısı ve açıklanan inertia değerleri

\begin{tabular}{lcccccc}
\hline Boyut & Tekil değer & Inertia & $\chi 2$ & $P$ & \multicolumn{2}{c}{ Açılanan inertia } \\
\cline { 6 - 7 } & & & & & Açıklanan & Toplamalı \\
\hline 1 & 0,077 & 0,006 & & & 0,961 & 0,961 \\
2 & 0,016 & 0,000 & 2,519 & 0,641 & 0,039 & 1 \\
Toplam & & 0,006 & & & 1 & 1 \\
\hline
\end{tabular}

Tablo 12 incelendiğinde satır ve sütun değişkenleri arasında bir ilişki bulunmamaktadır $\left(\chi^{2}(4)=2,519, p>, 05\right)$. Buna göre satır ve sütunların birbirinden bağımsız olduğu söylenebilir. Öğretmen adaylarının "matematik" sözcüğünü neye benzettiklerine yönelik ifadelerinin matematiğe yönelik tutum düzeyi ile ilişkili olmadığı anlaşılmaktadır. Öğretmen adaylarının "matematik" sözcüğünü benzettikleri kavrama yönelik benzetme nedenlerinin matematik başarı testi puan düzeyleri ile ilişkili olup olmadığını ortaya koymak üzere uyum analizi sonucunda elde edilen boyutlara ve inertia değerlerine ilişkin veriler Tablo 13'te yer almaktadır. 
Tablo 13. Öğretmen adaylarının benzetme nedenleri ve matematik başarısı düzeyi için boyut sayısı ve açıklanan inertia değerleri

\begin{tabular}{lcccccc}
\hline Boyut & Tekil değer & Inertia & $\chi 2$ & $P$ & \multicolumn{2}{c}{ Açıklanan inertia } \\
\cline { 6 - 7 } & & & & & Açıklanan & Toplamalı \\
\hline 1 & 0,250 & 0,063 & & & 0,786 & 0,786 \\
2 & 0,130 & 0,017 & 32,035 & $0,001^{*}$ & 0,214 & 1 \\
Toplam & & 0,079 & & & 1 & 1 \\
* $^{p}<0,05$ & & & & &
\end{tabular}

Tablo 13 incelendiğinde inertianın $0^{\prime}$ dan farklı olup olmadığına yönelik olarak yürütülen ki-kare testi sonucunda toplam inertianın 0 'dan farklı olduğu görülmektedir $\left(\chi^{2}(12)=32,035, p<, 05\right)$. Buna göre satır ve sütun değişkenleri arasında bir ilişki olduğu, satır ve sütunların birbirinden bağımsız olmadığı söylenebilir. Ayrıca toplam inertianın \%78,6'lık kısmının birinci boyut, \%21,4'lük kısmının ise ikinci boyut tarafından açıklandığı görülmektedir. İki boyut tüm değişkenliği açıklamaktadır.

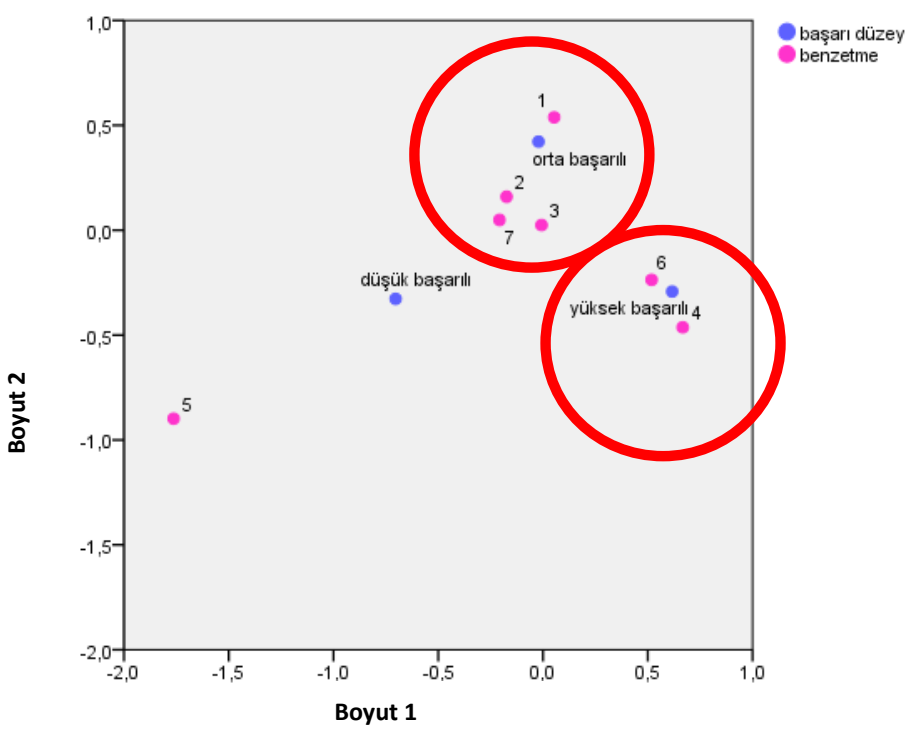

1: Gerektirdiklerinin olması durumu,

2: Matematiğe yönelik duygu durumu,

3: Yapılabilme durumu,

4: Yararlı olma durumu,

5: Matematiğe yönelik duygu ve yararlı olma durumu,

6: Matematiğe yönelik duygu ve gerektirdiklerinin olması durumu,

7: Matematiğe yönelik duygu ve yapılabilme durumu

Şekil 3. Öğretmen adaylarının benzetme nedenleri ve matematik başarısı düzeyi için satır ve sütun noktalarının düzlemde birlikte gösterimi

Şekil 3 incelendiğinde akademik başarı testinden yüksek puan alan öğretmen adaylarının matematiğin yararlı olma durumuna, matematiğe yönelik duygu ve gerektirdiklerinin olması durumuna yönelik ifadeleri kullandıkları gözlenmektedir. Başarı testinden orta düzeyde puan alan öğretmen adaylarının ise matematiğin gerektirdikleri, matematiğe yönelik duygu durumu, duygu ve yapılabilme durumuna yöneldikleri gözlenmektedir. Düşük puan alan öğretmen adaylarında ise belirgin bir ifade durumuna yönelme gözlenmemekle birlikte bazı öğrencilerin matematiğe yönelik duygu ve yapılabilme durumuna yönelik ifadeler de kullandıkları gözlenmektedir.

Bu bulgu öğrenme ve öğretme süreçlerini düzenlerken dikkate alınması gereken dinamikleri görmemize ve buna göre bir planlama yapılmasına yönelik önemli bir gösterge olabilir. Matematiğin uğraş isteyen bir alan olmasına yönelik ifadelerin ise başarısı düşük öğretmen adayları tarafından daha çok kullanıldığı dikkate alınırsa, bu durum matematik başarısı düşük olan öğretmen adaylarının matematiği zor bir ders olarak görmelerinden kaynaklanabilir. Bu nedenle tüm öğretmen eğitimi programlarında eğitim gören öğretmen adaylarının matematiğin herkes tarafından ulaşılabilir ve öğrenilebilir bir alan olduğuna yönelik ikna edilmesi gerekir. Aksi takdirde okul öncesi eğitim kurumlarından itibaren öğretilen matematiksel düşünme ve işlem yapma becerilerinin soyut bir işlem olmadan öteye gitmediği, içselleştirilemediği sonucuyla karşılaşmak durumunda kalırız. Öğretmen adaylarının "matematik" sözcüğünü benzetme nedenlerinin matematiğe yönelik tutum testi puanı düzeyi ile ilişkili olup olmadığını ortaya koymak üzere uyum analizi sonucunda elde edilen boyutlara ve inertia değerlerine ilişkin veriler Tablo 14 'te yer almaktadır.

Tablo 14. Öğretmen adaylarının “matematik” sözcüğünü benzetme nedenleri ve matematiğe yönelik tutum düzeyi için boyut sayısı ve açıklanan inertia değerleri

\begin{tabular}{lcccccc}
\hline Boyut & Tekil değer & Inertia & $\chi 2$ & $P$ & \multicolumn{2}{c}{ Açılklanan inertia } \\
\cline { 6 - 7 } & & & & & Açıklanan & Toplamalı \\
\hline 1 & 0,260 & 0,068 & & & 0,771 & 0,771 \\
2 & 0,142 & 0,020 & 35,351 & $0,000^{*}$ & 0,229 & 1 \\
Toplam & & 0,088 & & & 1 & 1 \\
\hline *p $<0,05$ & & & & &
\end{tabular}


Tablo 14 incelendiğinde inertianın $0^{\prime}$ dan farklı olup olmadığına yönelik olarak yürütülen ki-kare testi sonucunda toplam inertianın 0'dan farklı olduğu görülmektedir $\left(\chi^{2}(12)=35,351, p<, 05\right)$. Buna göre satır ve sütun değişkenleri arasında bir ilişki olduğu, satır ve sütunların birbirinden bağımsız olmadığı söylenebilir. Ayrıca toplam inertianın \%77,1'lik kısmının birinci boyut, \%22,9'luk kısmının ise ikinci boyut tarafından açıklandığı görülmektedir. İki boyut tüm değişkenliği açıklamaktadır.
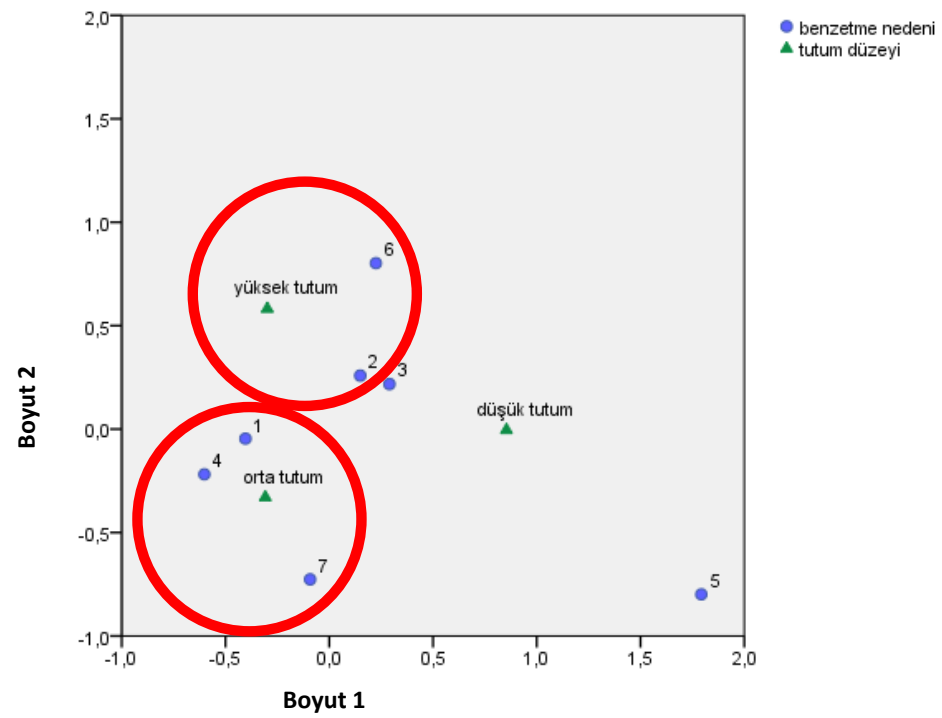

\author{
1: Gerektirdiklerinin olması \\ durumu, \\ 2: Matematiğe yönelik duygu \\ durumu, \\ 3: Yapılabilme durumu, \\ 4: Yararlı olma durumu, \\ 5: Matematiğe yönelik duygu ve \\ yararlı olma durumu, \\ 6: Matematiğe yönelik duygu ve \\ gerektirdiklerinin olması durumu \\ 7: Matematiğe yönelik duygu ve \\ yapılabilme durumu
}

Şekil 4. Öğretmen adaylarının benzetme nedenleri ve matematiğe yönelik tutum düzeyi için satır ve sütun noktalarının düzlemde birlikte gösterimi

Şekil 4 incelendiğinde yüksek tutum testi puanı alan öğretmen adaylarının matematiğe yönelik duygu durumuna, matematiğe yönelik duygu ve gerektirdiklerinin olması durumuna yöneldikleri gözlenmektedir. Orta düzeyde tutum testi puanı alan öğretmen adaylarının ise yararlı olma durumuna, gerektirdiklerinin olması durumuna ve hem matematiğe yönelik duygu hem de yapılabilme durumlarına yönelik ifadelere yöneldikleri anlaşılmaktadır. Düşük tutum testi puanı alan öğretmen adaylarının ise ifadelerinde belirgin bir duruma yönelimi olmadıkları tespit edilmiştir. Yapılabilme durumuna tüm düzeylerdeki öğretmen adaylarının benzer eğilim gösterdiği gözlenmektedir. Orta düzeyde tutum testi puanına sahip olan öğretmen adaylarının daha çok nedene yöneldikleri söylenebilir. Bu durum, buna yönelen öğretmen adaylarının sayılarının fazlalığından kaynaklanabilir. Matematiğin uğraş istemesine ve günlük hayatı kolaylaştırması, problemlere çözüm üretmesi ve vazgeçilmez görülmesine tutum testi puanları orta düzeyde olan öğretmen adayları daha çok önem verme eğilimindedirler. Matematiğe yönelik olumlu ya da olumsuz duyguya sahip olmaya yönelik ifadelere ise tutum testi puanı yüksek olan öğretmen adaylarının daha çok önem verdikleri söylenebilir. Bu durum beklenen bir durum olup öğretimin matematiğe yönelik olumlu duyguya sahip olmayı sağlayacak şekilde düzenlenmesini sağlamak üzere önemli bir etken olarak alınabilir.

Öğretmen adaylarının bilime ve bilim insanına yönelik imajları konusunda çok çalışma olmasına rağmen matematiğe yönelik imajlarına ilişkin yapılan çalışma sayısı sınırlıdır (Korkmaz, 2011). Bu çalışmanın konusu olan matematiğe yönelik imajlar ve bu imajların matematik başarısı ve tutumu arasındaki ilişkiyi açıklayan çalışmalara ise rastlanmamıştır. Bu bağlamda yukarıda sunulan çalışma bulgularına dayalı olarak elde edilen sonuçlar aşağıda verilmektedir.

\title{
SONUÇ ve TARTIŞMA
}

İlköğretim düzeyinde matematik öğretmekten sorumlu öğretmen adaylarının matematiğe yönelik imajlarını farklı değişkenler açısından belirlemeyi amaçlayan bu çalışmanın birinci aşamasında öğretmen adaylarının matematiğe yönelik imajlarını ortaya koymak üzere, "matematik" sözcüğü denildiğinde akıllarına gelen ilk ifadeler sorulmuş ve verilen yanıtlar "matematik konuları, matematiğin faydaları, matematiğe yönelik duyguları ve okul hayatlarına" ilişkin temalar altında organize edilmiştir. Öğretmen adaylarının matematik konularına yönelik ifadelerinde; en fazla problemler ve sayılara değindikleri gözlenmiştir. Matematik denildiğinde ilk akla gelen ifadeler arasında en az okul hayatlarına değinen öğretmen adayları bu tema altında ise en fazla öğretmen, en az sınıf ortamına dair ifadeler kullanmışlardır. Matematiğe yönelik duyguları içerisinde daha çok olumlu duygularını yansıtan ifadelere değinmişlerdir. Matematiğin faydalarına yönelik ifadeleri içerisinde de en fazla çözüm üretmeye yönelik ifadelere değinmişlerdir. Sunulan bu araştırma konusuna benzer şekilde öğretmen adaylarının "matematik" sözcüğünü duyduklarında ilk akıllarına gelenleri yansıttıkları ifadeleri araştıran araştırmacılar ve bu araştırmacılar tarafından raporlanan araştırma bulguları (Altun, 2010; Baykul, 2014; Goodwin, Bowman, Wease, Keys, Fullwood ve Mowery, 2014; Hersh, 1997; Umay, 2003) yer almaktadır. Alan yazında öğretmen adaylarının matematik denildiğinde akıllarına ilk gelen ifadeler arasında matematiğin faydalarının yansıtıldığı (Baykul, 2014; Goodwin vd., 2014; Hersh, 1997; Umay, 2003); matematik konularının geldiği, matematiğin sayılar, geometrik şekiller, fonksiyonlar vb. için özellikleri ve aralarındaki ilişkiyi incelediğini ifade eden (Altun, 2010); matematiğe yönelik daha çok olumlu duyguların yansıtıldığı (Goodwin vd., 2014) çalışmalar bulunmaktadır. Bulgular, öğretmen adaylarının 
"matematik" sözcüğünü duyduklarında akıllarına çoğunlukla matematik konuları bunlar arasında da ise daha fazla sayılar konusun geldiğini göstermektedir. İlginç bir şekilde öğretmen adaylarına benzer şekilde bu soru öğrencilere sorulduğunda da onların da akıllarına çoğunlukla sayıların geldiğini ortaya koyan çalışma bulguları yer almaktadır (Martin ve Gourley-Delaney, 2014; TolukUçar, Pişkin, Akkaş ve Taşçı, 2010). Bu bulgular öğretmenlerin sahip oldukları imajların öğrencilere yansıdığını, öğrencilerin de öğretmenleriyle benzer imajlara sahip olduklarını göstermektedir. Bu bulgu öğretmen adaylarının matematiğe yönelik konu ve içerik bağlamından daha fazla imaja sahip olmaları gerektiğini ortaya koymakta ve öğretmen eğitimcilerine ve program yapıcılara mesaj vermektedir. Aksi takdirde matematik soyut yaşamdan uzak kavram ve içeriğe sahip bir alan olarak algılanmaya devam edecek ve yaşama yönelik boyutu ihmal edilecektir. Öğretmen adayları ifadelerinde nadiren sınıf ortamına değinmişlerdir. Bu durum öğretmen adaylarının matematik ile ilgili imajlarında sınıf ortamı ya da öğretici rolündeki öğretmenlerin daha az yer aldığını gösterebilir.

Programlara göre iMÖ, FBÖ ya da isÖ öğretmen adayları için "matematik" sözcüğünün ilk olarak akla getirdiği ifadelerin farklılaşması istatistiksel olarak anlamlı değil iken sınıf düzeylerine göre anlamlı bir şekilde farklılaşmaktadır. Sınıf düzeylerine göre yapılan analizlerde matematik denildiğinde matematik konularını daha çok dördüncü sınıf düzeyindeki öğretmen adayları belirtirken; matematiğin faydaları, matematiğe yönelik duyguları ve okul hayatına yönelik ifadeleri ise birinci sınıf düzeyindeki öğretmen adayları daha çok belirtmiştir. Bu bağlamda öğretmen yetiştirme (lisans) programlarının bir çıktısı olarak öğretmen adaylarının matematik deyince akıllarına ilk ve daha çok matematik dersi içeriğine yönelik ifadeleri getirdiği söylenebilir. Programa yeni başlayan öğretmen adaylarının ise hedeflere, öğrenme yaşantılarına ya da sınama durumuna yönelik ifadelere daha çok değindikleri gözlenmektedir. Öğretmen adaylarının matematiğe yönelik imajları bağlamında; sınıf düzeyinde akıllarına ilk gelen ifadeler karşılaştırıldığında ise bu ifadelerin değiştiği ve bu sonuçta öğretmen yetiştirme programı sonrası bir değişim söz konusu olduğu söylenebilir.

"Matematik" sözcüğünü neye benzettikleri sorulduğunda ise öğretmen adaylarının yanıtları evren, hayat ve araç kategorileri altında derlenmiştir. Öğretmen adaylarının kullanma sıklıkları açısından sırasıyla evren temasında uzay ve doğa; hayat teması altında hayatın kendisi, hayatın gerekleri ve hayattaki kurallar; araçlar temasında ise eğlence araçları ve karmaşık araçlar kavramlarını içeren ifadeler kullandıkları gözlenmiştir. Öğretmen adaylarının matematiği hayatın bir gereği olarak düşündükleri ve hayata benzettiklerine yönelik ifadeleri diğer araştırma bulgularıyla da örtüşmektedir (Çalışıcı ve Özçakır Sümen, 2019; Erdoğan, Yazlık ve Erdik, 2014; Güler vd., 2012; Güner, 2013). Hizmet içindeki öğretmenler ve öğrencilerle yapılan bazı araştırmalarda (Goodwin vd., 2014; Gür, Hangül ve Kara, 2014; Martin ve Gourley-Delaney, 2014) da matematiğin yaşam için gerekli görüldüğü ifade edilmiştir. Öğretmen adayları, daha çok matematiği hayata benzettikleri ve matematiğin hayat için gerekli olduğunu ifade etmelerine rağmen; matematik denilince akıllarına gelen ilk ifadenin, hayatla ilişkili olmadığı ve matematik dersinin ya da disiplinin konularına ilişkin olduğu gözlenmektedir. Öğretmen adayları aynı zamanda matematiğin zorluğuna, karmaşa-karışıklık yarattığına yönelik ifadelerden daha fazla eğlenceli bir alan olduğuna yönelik görüş bildirmişlerdir. Öğretmen adaylarının matematiği eğlenceli görmelerine ilişkin benzer bulgular diğer araştırmalarda yer almaktadır (Çalışıcı ve Özçakır Sümen, 2019; Guillaume ve Kirtman, 2010; Güner, 2013; Güveli, İpek, Atasoy ve Güveli, 2011; Şahin, 2013). Goodwin vd. (2014) de yaptıkları araştırmada hizmetteki öğretmenlerin de matematiğin eğlenceli olduğunu ifade ettiklerine yönelik bulgular sunmaktadırlar. Yetim Karaca ve Ada'nın (2018) çalışmalarında ise öğrencilerin birçoğu matematiği zor ve karmaşık görürken, bir kısmı eğlenceli ve kolay görmüştür. Bahadır ve Özdemir'in (2012) çalışmalarında da öğrenciler tarafından matematik oyun, tatlı ya da korku öğesi olarak görülmüştür. Bu bağlamda, öğretmen adaylarının duyuşsal birikimlerinin, matematiğe karşı olumlu duygulara sahip olmalarının gelecekte bu özelliklerini öğrencilerine yansıtacaklarını varsayarsak; gelecekteki matematik eğitimine yönelik bir bakış açısı geliştirmemize ve öğrenme ortamlarının daha eğlenceli ve zevkli bir içerikle sunulacağına yönelik bir anlayış geliştirebiliriz.

"Matematik" sözcüğünü benzettikleri kavramları gerekçelendirme ifadeleri analiz edildiğinde bu ifadeler "yapılabilme durumu, matematiğe yönelik duygu durumu, gerektirdiklerinin olması durumu ve yararlı olma durumuna" ilişkin temalar altında toplanmıştır. Kullanma sıklıkları sırası açısından yapılabilme durumu teması bağlamında zor, kolay ve sonradan kolay gelmesi; matematiğe yönelik duygu durumu teması bağlamında olumlu duygu, olumsuz duygu, yapınca olumlu duygu ve sonradan olumsuz duyguya sahip olunması; gerektirdiklerinin olması teması bağlamında ise aşamalı olması ve uğraş istemesi; yararlı olması bağlamında ise günlük hayatı kolaylaştırması, problemlere çözüm getirmesi, vazgeçilmez görülmesi kavramlarını içeren ifadeleri kullandıkları gözlenmiştir. Öğretmen adaylarının kullandıkları ifadelerde yer alan matematiği zor görmelerine (Çalışıı ve Özçakır Sümen, 2019; Güner, 2013; Güveli, İpek, Atasoy ve Güveli, 2011; Şahin, 2013), matematiğe yönelik olumlu duyguya sahip olma durumlarına (Güner, 2013; Güveli, İpek, Atasoy ve Güveli, 2011; Şahin, 2013), matematiğin günlük hayatı kolaylaştırmasına (Güner, 2013), vazgeçilmez görülmesine (Şahin, 2013), matematiğe yönelik olumsuz duyguya sahip olma durumlarına (Çalışıcı ve Özçakır Sümen, 2019; Güveli, İpek, Atasoy ve Güveli, 2011) ilişkin verdikleri cevaplar benzer bulgulara sahip diğer araştırmalarda da gözlenmektedir. Bu araştırmaya katılan öğretmen adaylarının çoğu matematiğe yönelik olumlu duyguya sahip olduklarını belirtmişlerdir. Bu bulguya benzer bir bulgu Goodwin vd. (2014) tarafından öğretmenlerle yapılan başka bir araştırmada da elde edilmiştir. Bu durum, öğretmen adaylarının gelecekte olumlu duygulara sahip öğretmenler olacaklarının göstergesi olarak kabul edilebilir. Öğretmen adayları nadiren cevaplarında benzetme gerekçesi olarak matematiğin gerektirdiklerinin olmasına yönelik ifadelere değinmişlerdir. Bu bulgu Sterenberg'in (2008) öğretmenler ile yaptığı çalışmada elde ettiği bulguyla da örtüşmektedir. Araştırmaya katılan öğretmenler aynı zamanda matematiğin çaba gerektirdiğini de belirtmişlerdir. Bu bulgu, öğretmen adaylarının daha çok matematiğe yönelik olumlu duyguya sahip olmalarıyla da örtüşmektedir. Matematik imajına yönelik diğer araştırmalarda; matematiğin birçok konudan oluştuğuna (Güveli, İpek, Atasoy ve Güveli, 2011), geleneksel olarak matematiğin ezberle 
öğretilebileceğine (Ball, 1990), matematiğe karşı tarafsız olunduğuna (Guillaume ve Kirtman, 2010) yönelik farklı araştırma bulguları da söz konusudur.

Öğretmen adaylarının matematiğe yönelik imajlarında öğrenim gördükleri program ve sınıf düzeyine göre anlamlı bir farklılaşmanın olup olmadığını ortaya koymak üzere, "matematik" sözcüğünü benzetmeleri için elde edilen sonuçlar şöyledir: (a) Öğretmen adayları en çok hayata, en az evrene değinmişlerdir. (b) Farklı program türleri ve sınıf düzeylerine göre anlamlı bir şekilde farklılaşmamaktadır. IMÖ, FBÖ ya da isö programlarına devam eden öğretmen adayları için "matematik" sözcüğünün benzetildiği ifadelerin farklılaşması istatiksel düzeyde anlamlı değildir. Bu durum istatiksel olarak programa yeni başlayan ve programı tamamlayan öğretmen adayları için sınıf düzeyinde anlamlı farklılık oluşturmuştur. Kuzu, Kuzu ve Sıvacı'nın (2018) çalışmasında ise iMÖ programına devam eden öğretmen adaylarının isÖ ve FBÖ programına devam eden öğretmen adaylarına göre daha olumlu benzetmeler kullanmıştır. Tarim, Bulut Özsezer ve Canbazoğlu (2017) ise isÖ programına devam eden öğretmen adaylarının sıklıkla matematiği hayata benzettiklerini ifade etmektedir.

Öğretmen adaylarının matematiğe yönelik imajlarında öğrenim gördükleri program ve sınıf düzeyine göre anlamlı bir farklılaşmanın olup olmadığını ortaya koymak üzere, "matematik" sözcüğünü benzetme nedenleri için elde edilen sonuçlar şöyledir: (a) Öğretmen adayları en çok matematiğe yönelik duygu durumuna, en az gerektirdiklerinin olması durumuna değinmişlerdir. Matematiğe yönelik duygu ve yapılabilme durumuna yönelik ifadelerde birden fazla açıklama yapmışlardır. (b) Farklı sınıf düzeylerine göre ifadeleri istatistiksel olarak anlamlı bir şekilde farklılaşmamaktadır. Programa yeni başlayan ve programı tamamlayan öğretmen adayları için "matematik" sözcüğünü benzetme nedenlerinin farklılaşması istatistiksel olarak anlamlı değildir. (c) Farklı program türlerine göre ise anlamlı bir şekilde farklılaşmaktadır. Yararlı olma durumu ile birden fazla görüş bildirme bakımından matematiğe yönelik duygu ve gerektirdiklerinin olması durumunu iMö programında öğrenim gören öğretmen adayları belirtirken; gerektirdiklerinin olması durumu, matematiğe yönelik duygu durumu ile birden fazla görüş bildirme bakımından matematiğe yönelik duygu ve yapılabilme durumunu ise FBÖ programında gören öğrenciler; yapılabilme durumu ile birden fazla görüş bakımından matematiğe yönelik duygu ve yararlı olma durumunu isö programında öğrenim gören öğretmen adayları daha çok belirtmişlerdir. Öğretmen adaylarının matematiğe yönelik imajları bağlamında; programlara göre bir değişim söz konusu olmuştur. Duygu durumunun yanı sıra isö programında öğrenim gören öğretmen adayları matematiğin yapılabilmesini ön plana çıkarırken, IMÖ programında öğrenim gören öğretmen adayları matematiğin yararlarını, FBÖ programında öğrenim gören öğretmen adayları ise matematiğin gerektirdiklerini ön plana çıkarmışlardır. Güner'in (2013) benzer bir konuda yürüttüğü araştırmasında da benzer şekilde iMÖ’de öğrenim gören öğretmen adayları ifadelerinde matematiğin faydalarına yönelerek matematiğin hayatın kendisi olduğunu belirtmişlerdir. Matematiğe yönelik duygu durumuna yönelik ifadelere Şahin'in (2013) araştırmasında da bu araştırmada olduğu gibi FBÖ programına kayıtlı öğretmen adayları yönelirken, Güner'in (2013) araştırmasında isÖ programına kayıtlı öğretmen adayları yönelmişlerdir. Matematiğin yararlı olmasına iMÖ programına kayıtlı öğretmen adaylarının daha fazla yönelmesi beklenen bir durum iken, matematiğe yönelik duygulara yönelik ifadelere FBÖ programına kayıtlı öğretmen adaylarının yönelmesi daha az beklenen bir durum olarak değerlendirilmiştir. Öğretmen adaylarının tamamı için matematiğe yönelik olumlu duyguya yönelme durumuna yönelme beklenirken, bu farklılığın FBÖ programına kayıtlı öğretmen adaylarının yönelmesi şeklinde kendini göstermesinin, daha çok fen öğretiminin içeriğine dayalı olarak öğrenmeöğretme ortamlarının düzenlenmesinden kaynaklandığı söylenebilir.

Öğretmen adaylarının matematik başarıları ve matematiğe yönelik tutumlarında öğrenim gördükleri program ve sınıf düzeyine göre anlamlı bir farklılaşmanın olup olmadığını ortaya koymak üzere yapılan istatistiksel analizler sonucunda elde edilen bulgular şöyledir: (a) Hem matematik başarı puanları hem de matematiğe yönelik tutum puanları; ìÖ programında öğrenim gören öğretmen adaylarının lehine farklılık göstermektedir. IMÖ programında öğrenim gören öğretmen adaylarının matematik başarıları ve matematiğe yönelik tutumları, FBÖ ve isÖ öğretmen adaylarınınkinden daha yüksektir. (b) Hem matematik başarı puanları hem de matematiğe yönelik tutum puanları sınıf düzeyine göre anlamlı bir şekilde farklılaşmamaktadır. Matematik başarısı için yapılan bir araştırmada benzer şekilde IMÖ öğretmen adaylarının matematik başarılarının FBÖ ve isÖ öğretmen adaylarının matematik başarılarından daha yüksek olduğu belirtilmiştir (Gökçek ve Güneş, 2011). Matematiğe yönelik tutum için yapılan araştırmalarda da benzer şekilde íMÖ öğretmen yetiştirme programına devam edenlerin matematiğe yönelik tutumlarının daha yüksek olduğu anlaşılmaktadır (Boran, Aslaner ve Çakan, 2013; Duru, Akgün ve Özdemir, 2005; Kuzu, Kuzu ve Sıvacı, 2018). Bu durum iMÖ programında yer alan matematik ders konularının fazlalığı, matematik alanındaki temel ve seçmeli ders sayısının nicelik ve içerik olarak farklı olması; öğretmen adaylarının programa girerken hazırbulunuşluk düzeylerinin diğer programlarda yer alan öğretmen adaylarına göre daha yüksek olması ile açıklanabilir.

Öğretmen adaylarının matematiğe yönelik imajları ile matematik başarısı testi puanları ve matematiğe yönelik tutum puanları arasında ilişkinin olup olmadığını ortaya koymak üzere, "matematik" sözcüğü denildiğinde öğretmen adaylarının ilk akıllarına gelen ifadeler için elde edilen sonuçlar şöyledir: (a) Öğretmen adaylarının tamamı için matematik başarısı ile ilişkilidir. Bu bağlamda, matematiğin faydalarına yüksek puan alan öğretmen adaylarının, matematik konularına ise orta düzeyde puan alan öğretmen adaylarının yönelme eğiliminde olduğu anlaşılmaktadır. Okul hayatına hem orta hem de düşük düzeyde puan alan öğretmen adayları benzer şekilde yönelmektedir. Düşük düzeyde başarı testi puanı alan öğretmen adayları ise okul hayatının yanı sıra matematiğe yönelik duygulara da benzer şekilde yönelmektedirler. Başarı testi puanı yüksek olanların matematiğin faydalarına, başarı puanı düşük olanların ise okul hayatı ve duygulara önem verdikleri söylenebilir. (b) Öğretmen adaylarının tamamı için matematiğe yönelik tutum ile ilişkilidir. Bu bağlamda, matematiğe yönelik duygulara yüksek tutum testi puanı alan öğretmen adaylarının, matematik konularına orta düzeyde tutum testi puanı alan öğretmen adaylarının, okul hayatına düşük tutum testi 
puanı alan öğretmen adaylarının yönelme eğiliminde olduğu anlaşılmaktadır. Matematiğin faydalarına yönelik ifadelere ise öğretmen adaylarının belirgin bir yönelimleri bulunmamaktadır.

Öğretmen adaylarının matematiğe yönelik imajları ile matematik başarı testi puanları düzeyi ve matematiğe yönelik tutum testi puanları düzeyi arasında ilişkinin olup olmadığını ortaya koymak üzere, "matematik" sözcüğünü benzetmeleri için elde edilen sonuca göre; öğretmen adaylarının tamamı için matematik başarısı testi puanları ve matematiğe yönelik tutum testi puanları düzeyleri ile ilişkili değildir.

Öğretmen adaylarının matematiğe yönelik imajları ile matematik başarı testi puan düzeyleri ve matematiğe yönelik tutum testi puan düzeyleri arasında ilişkinin olup olmadığını ortaya koymak üzere, "matematik" sözcüğünü benzetme nedenleri için elde edilen sonuçlar şöyledir; (a) Öğretmen adaylarının tamamı için matematik başarısı ile ilişkilidir. Bu bağlamda, yararlı olma durumuna ve birden fazla görüş bakımından matematiğe yönelik duygu ve gerektirdiklerinin olması durumuna yüksek başarılı öğretmen adaylarının yönelme eğiliminde olduğu gözlenmektedir. Gerektirdiklerinin olması durumuna, matematiğe yönelik duygu durumuna, yapılabilme durumuna ve birden fazla görüş bildirme durumu bakımından matematiğe yönelik duygu ve yapılabilme durumuna orta düzeyde başarı testi puanı alan öğretmen adaylarının yönelme eğiliminde olduğu anlaşılmaktadır. Düşük başarı testi puanı alan öğretmen adayları ise belirgin bir yönelme göstermemekle birlikte, birden fazla görüş bakımından matematiğe yönelik duygu ve yapılabilme durumuna yönelik ifadeler kullanmaktadırlar. (b) Öğretmen adaylarının tamamı için matematiğe yönelik tutum testi puanı ile ilişkilidir. Bu bağlamda, matematiğe yönelik duygu durumuna, birden fazla görüş bildirme bağlamında matematiğe yönelik duygu ve gerektirdiklerinin olması durumuna yüksek tutum testi puanı alan öğretmen adaylarının; yararlı olma durumuna, gerektirdiklerinin olması durumuna, birden fazla görüş bildirme bağlamında matematiğe yönelik duygu ve yapılabilme durumuna ise orta düzeyde tutum testi puanı alan öğretmen adaylarının yöneldiği gözlenmektedir. Düşük tutum testi puanı alan öğretmen adaylarının belirgin bir yönelimi bulunmamaktadır. Yapılabilme durumuna yönelik ifadelerde ise tüm öğretmen adaylarının benzer eğilim gösterdiği söylenebilir.

\section{ÖNERILER}

$\mathrm{Bu}$ araştırma çalışma grubunun seçimi ile ilgili süreç ve bulguların genellenebilirliği açısından bazı sınırlılıklara sahiptir. Gelecekte bu konuda yapılan çalışmalar olasılığa dayalı rastgele örnekleme yoluyla belirlenen bir grupta çalışılabilir ve bulgular evrene genellenebilir. Deneysel bir çalışma deseni ile öğretmen adaylarının matematiğe yönelik imajlarını, başarı ve tutumlarını etkileşimli olarak nasıl değiştirilebileceğine yönelik öngörüde bulunulmasına katkı sağlanabilir. Ayrıca bu çalışma tarama deseni kesitsel bir çalışma olarak yürütülmüştür. Boylamsal bir çalışma ve Kohort Tarama (izleme) deseni ile yıllara göre aynı öğretmen adayları üzerinde veri toplanılarak yürütülebilir.

Araştırma bulguları incelendiğinde programlara ve sınıf düzeylerine göre matematiğe yönelik imajlarda, başarı ve tutum düzeyleri açısından gruplar arasında farklılık olduğu gözlenmektedir. Bu çalışma, daha fazla öğretmen adayını matematik ile ilgili iş ve işlemleri yapabilecekleri, matematiği başarabilecekleri konusunda ikna etmeyi amaçlayanlar için bir öneri sunmaktadır. Öğretmen adaylarını matematiğin zor bir disiplin olmadığına ikna etmeye çalışmak yerine, matematik eğitimcileri, öğretmen adaylarının matematikle uğraşırken daha rahat olmalarına yardımcı olmaya çalışmalı ve bu öğrencilerin matematiksel olarak başarılı olanlardan radikal olarak farklı olmadığı konusunda onları ikna etmelidir. Elde edilen bulgular doğrultusunda öğretmen eğitimi sürecinde öğretim elemanlarının içeriği aktarmaktan ziyade yaşama, uygulamaya yönelik etkinliklere yer vermesi önerilebilir. Bu bağlamda öğretmen adaylarının aldıkları matematik eğitiminin yaşama ve uygulamaya yönelik çıktılara ulaşabilmesi için matematik tarihi, matematikçi öykülerinin kullanımı, öğrenme ortamlarında gerçek matematikçilere, bilim insanlarına maruz kalma ve/veya öğrencilerin matematiği keşfetme veya gerçek hayattaki matematiksel durumlarla çalışma fırsatlarının arttırılması, matematikle ilgili öğrenme güçlükleri, olumsuz duyguya sahip olanların, mücadele edenlerin matematikle ilgilenmelerine ve matematikçilerle özdeşleşmelerine yardımcı olabilecek olanaklardır.

"Matematik" sözcüğü denildiğinde son sınıftaki öğretmen adaylarının ilk akıllarına gelenler arasında öğretmen yetiştirme programlarının daha çok içerik boyutuna ilişkin ifadeleri yansıtmaları söz konusu iken, programa yeni başlayan öğretmen adaylarının ise ifadelerinde hedeflere, öğrenme yaşantılarına ya da sınama durumuna yönelik ifadelere daha çok değindikleri gözlenmektedir. Bu bağlamda, program türü ne olursa olsun, öğretmen eğitimi programını oluşturan öğelerin birinde meydana gelen bir aksaklık diğerlerini de etkileyeceği için hazırlanan programlarda programın tüm öğelerinin göz önünde bulundurulması ve aralarında dinamik bir ilişkinin oluşturulması önerilmektedir. Tüm öğretmen eğitimi programlarında yer alan içerikte konuların özelliklerine göre daha fazla matematiğin yaşama entegrasyonu, diğer disiplin alanlarıyla ilişkisi, olumlu duyguları geliştiren, öğrencilerin matematikçilerin çalışmaları ile kendilerini özdeşleştiren öğelere yer verilmelidir.

\section{Etik Kurul Onay Bilgileri}

Veri toplama sürecinden önce uygulamanın yapılabilmesi için ilgili resmi kurumun Etik Komisyonu'ndan 21.07.2015 tarihli 35853172/433_2306 sayılı etik kurul onayı alınmıştır. 


\section{KAYNAKÇA}

Alpar, R. (2013). Uygulamalı çok değişkenli istatistiksel yöntemler (4. baskı). Ankara: Detay.

Altun, M. (2010). Eğitim fakülteleri ve ilköğretim öğretmenleri için matematik öğretimi. İstanbul: Alfa Yayınları.

Anderson, D.S., \& Piazza, J.A. (1996). Changing beliefs: Teaching and learning mathematics in constructivist preservice classrooms. Action in Teacher Education, 18(2), 51-62.

Atılgan, H. (2006). Eğitimde ölçme ve değerlendirme. (Ed. Atılgan, H.) Ankara:Anı Yayıncılık.

Bahadır, E., \& Özdemir, A. Ş. (2012). Illköğretim 7. sınıf öğrencilerinin matematik kavramına ilişkin sahip oldukları zihinsel imgeler. International Journal of Social Science Research, 1(1), 26-40.

Baydar, S. C., \& Bulut, S. (2002). Öğretmenlerin matematiğin doğası ve öğretimi ile ilgili inançlarının matematik eğitimindeki önemi. Hacettepe Üniversitesi Eğitim Fakültesi Dergisi, 23, 62-66.

Ball, D. L. (1990). Breaking with experience in learning to teach mathematics: The role of a preservice methods course. For the learning of Mathematics, 10(2), 10-16.

Baykul, Y. (2014). Ortaokulda matematik öğretimi (5-8. Sınıflar). (Geliştirilmiş 2. Baskı). Ankara: Pegem Akademi.

Boran, A. İ., Aslaner, R., \& Çakan, C. (2013). Birinci sınıf öğretmen adaylarının matematiğe yönelik tutumlarının bazı değişkenlere göre incelenmesi. Turkish Journal of Computer and Mathematics Education, 4(1), 1-19.

Can. A. (2013). SPSS ile bilimsel araştırma sürecinde nicel veri analizi. (2. baskı). Ankara: Pegem Akademi.

Chambers, D. W. (1983). Stereotypic images of the scientist: The draw-a-scientist test. Science Education, 67, 255-265.

Çalışıcl, H., \& Özçakır Sümen, Ö. (2019). Pre-service mathematics' about mathematics concept: a metaphor study. Internatioanl Journal of Educational Studies in Mathematics, 6(3), 108-123.

Demirel, Ö. (2012). Eğitimde program geliştirme. (18. baskı). Ankara: Pegem Akademi.

Doğan, M. (2014). Aday öğretmenlerin matematik hakkındaki düşünceleri: Türk ve İngiliz öğrencilerin karşılaştırılması. Yüzüncü Yıl Üniversitesi Eğitim Fakültesi Dergisi, 1(2), 1-14.

Duatepe, A., \& Çilesiz S. (1999). Matematik tutum ölçeği geliştirilmesi. Hacettepe Üniversitesi Eğitim Fakültesi Dergisi, 16-17, 45-52.

Duru, A., Akgün, L., \& Özdemir, M.E. (2005). İlköğretim öğretmen adaylarının matematiğe yönelik tutumlarının incelenmesi. Kazım Karabekir Eğitim Fakültesi Dergisi, 11, 520-536.

Eraslan, A. (2009). Finlandiya'nın PISA'daki başarısının nedenleri: Türkiye için alınacak dersler. Necatibey Eğitim Fkültesi Elektronik Fen ve Matematik Ĕgitimi Dergisi, 3(2), 238-248.

Erdoğan, A., Yazlık, D. Ö., \& Erdik, C. (2014). Mathematics teacher candidates' metaphors about the concept of "mathematics". International Journal of Education in Mathematics, Science and Technology, 2(4), 289-299.

Ertürk, S. (2016). Eğitimde "program" geliştirme. (2. baskı). Ankara: Edge Akademi Yayıncılık.

Goodwin, D., Bowman, R., Wease, K., Keys, J., Fullwood, J., \& Mowery, K. (2014). Exploring the relationship between teachers' images of mathematics and their mathematics history knowledge. Philosopy of Mathematics Education, 28, 1-15.

Gökçek, T., \& Güneş, G. (2011). Öğrenciler matematik öğretmenini nasıl algılıyor? Mehmet Akif Ersoy Üniversitesi Sosyal Bilimler Enstitüsü Dergisi, 3(4), 1-9.

Guillaume, A. M., \& Kirtman, L. (2010). Mathematics stories: Preservice teachers' images and experiences as learners of mathematics. Issues in Teacher education, 19(1), 121-143.

Güler, G., Akgün, L., Öçal, M. F., \& Doruk, M. (2012). Matematik öğretmeni adaylarının matematik kavramına ilişkin sahip oldukları metaforlar. Eğitim ve Öğretim Araştırmaları Dergisi, 1(2), 25-29.

Güner, N. (2013). Öğretmen adaylarının matematik hakkında oluşturdukları metaforlar. NWSA-Education Sciences, 8(4), 428-440.

Gür, H., Hangül, T., \& Kara, A. (2014). Ortaokul ve lise öğrencilerinin "matematik" kavramına ilişkin sahip oldukları metaforların karşılaştırılması. The Journal of Academic Social Science Studies, 25(1), 427-444.

Güveli, E., İpek, A. S., Atasoy, E., \& Güveli, H. (2011). Sınıf öğretmeni adaylarının matematik kavramına yönelik metafor algıları. Turkish Journal of Computer and Mathematics Education, 2(2), 140-159.

Hair. J.F., William. Jr.. Black. C., Babin. B.J., \& Anderson. R.E. (2014). Multivariate data analysis (7. baskı.). London: Pearson Publications. New York: Springer Science+Business Media.

Hersh, R. (1997). What is mathematics, really? Oxford: Oxford University Press.

Kline, R. B. (2005). Principle and practice of structural equation modelling. (2. baskı). New York: The Guilford Press.

Korkmaz, H. (2011). The Contribution of Science Stories Accompanied by Story Mapping to Students' Images of Biological Science and Scientists. Electronic Journal of Science Education. 15(1). ISSN 1087-3430 (WILSON).

Kuzu, O., Kuzu, Y., \& Sivacı, S.Y. (2018). Preservice teacher' attitudes and metaphor perceptions towards mathematics. Çukurova Üniversitesi Eğitim Fakültesi Dergisi, 47(2), 897-931.

Leech, N. L., \& Onwuegbuzie, A. J. (2009). A typology of mixed methods research designs. Qual Quant, 43, 265-275.

Martin, L., \& Gourley-Delaney, P. (2014). Students' images of mathematics. Instructional Science, 42(4), 595-614.

MEB (Milli Eğitim Bakanlığı) (2017). PISA 2015 ulusal raporu. [Çevrim-içi: http://pisa.meb.gov.tr/wp-content/uploads/2013/07/PISA-2009-UlusalOn-Rapor.pdf, Erişim tarihi: Aralık 2017.]

MEB (Milli Eğitim Bakanlığı) (2014). TIMMS 2011 ulusal matematik ve fen raporu 8. sınıflar. [Çevrim-içi: http://timss.meb.gov.tr/wpcontent/uploads/TIMSS-2011-8-Sinif.pdf, Erişim tarihi: Aralık 2017.] 
MEB (Milli Eğitim Bakanlığı) (2011). TIMMS 2007 ulusal matematik ve fen raporu 8. sınıflar. [Çevrim-içi: http://timss.meb.gov.tr/wpcontent/uploads/timss_2007_ulusal_raporu.pdf, Erişim tarihi: Aralık 2017.]

MEB (Milli Eğitim Bakanlığı) (2010a). PISA 2009 ulusal ön rapor. [Çevrim-içi: http://pisa.meb.gov.tr/wp-content/uploads/2013/07/PISA-2009Ulusal-On-Rapor.pdf, Erişim tarihi: Aralık 2017.]

MEB (Milli Eğitim Bakanlığı) (2010b). PISA 2006 ulusal nihaî rapor. [Çevrim-içi: http://pisa.meb.gov.tr/wp-content/uploads/2013/07/PISA2006Ulusal-Nihai-Rapor.pdf, Erişim tarihi: Aralık 2017.]

MEB (Milli Eğitim Bakanlığı) (2005). PISA 2003 projesi ulusal nihaî rapor. [Çevrim-içi: http://pisa.meb.gov.tr/wp-content/uploads/2013/07/PISA2003-Ulusal-Nihai-Rapor.pdf, Erişim tarihi: Aralık 2017.]

MEB (Milli Eğitim Bakanlı̆̆ı) (2003). TIMMS 1999 ulusal rapor. [Çevrim-içi: http://timss.meb.gov.tr/wpcontent/uploads/timss_1999_ulusal_raporu.pdf, Erişim tarihi: Aralık 2017.]

Miles, M.B., \& Huberman, A.M. (1994). Qualitative data analysis: an expanded sourcebook. (2. baskı). California: SAGE Publications.

Umay, A. (2003). Matematiksel muhakeme yeteneği. Hacettepe Üniversitesi Eğitim Fakültesi Dergisi, 24, 234-243.

Petty, R.E., \& Cacioppo, J.T. (1986). Communication and persuasion, central and peripheral toutes to attitude change. New York:Springer-Verlag.

Saban, A. (2004). Giriş düzeyindeki sınıf öğretmeni adaylarının “öğretmen” kavramına ilişkin ileri sürdükleri metaforlar. Türk Eğitim Bilimleri Dergisi, 2(2), 131-155.

Sam, L. C. (1999). Public images of mathematics. Doctoral Dissertation. University of Exeter.

Sam, L. C., \& Ernest, P. (2008). A survey of public images of mathematics. Research in Mathematics Education, 2, 193-206.

Sterenberg, G. (2008). Investigating teachers' images of mathematics. Journal of Mathematics Teacher Education, 11(2), 89-105.

Şahin, B. (2013). Öğretmen adaylarının "matematik öğretmeni", "matematik" ve "matematik dersi" kavramlarına ilişkin sahip oldukları metaforik algılar. Mersin Üniversitesi Ĕgitim Fakültesi Dergisi, 9(1), 313-321.

Tabachnick, B. G., \& Fidel, L. S. (2014). Using Multivariate Statistics. (6. baskı). USA: Pearson Education Limited.

Tarim, K., Özsezer, M., \& Canbazoğlu, H. B. (2017). Sınıf öğretmeni adaylarının matematik ve matematik öğretimine ilişkin algıları. Journal of Kirsehir Education Faculty, 18(3), 1032-1052.

Thomas, J. A., Pedersen, J. E., \& Finson, K. (2001). Validaitng the draw-a-science-teacher-test checlist (DASTT-C): Exploring mental models and teacher beliefs. Journal of Csience Teacher Education, 12(3), 295-310.

Toluk-Uçar, Z., Pişkin, M., Akkaş, E.N. ve Taşçı, D. (2010). Elementary students' beliefs about mathematics, mathematics' teachers and mathematicians. Eğitim ve Bilim, 35(155), 131-144.

Tyler, R. W. (1949). Basic principle of curriculum and instruction. Chicago: The University of Chicago Press.

Yalaz Atay, D. (2003). Öğretmen eğitiminin değişen yüzü. İstanbul: Nobel.

Yetim Karaca, S., \& Ada, S. (2018). Öğrencilerin matematik dersine ve matematik öğretmenine yönelik algılarının metaforlar yardımıyla belirlenmesi. Kastamonu Eğitim Dergisi, 26(3), 789-800. 